\title{
Buffering effects for negative life events: the role of material, social, religious and personal resources
}

This is a post-peer-review, pre-copyedit version of an article published in Journal of Happiness Studies. The final authenticated version is available online at: http://dx.doi.org/10.1007/s10902018-9995-x

Ursina Kuhn, FORS, C/o Université de Lausanne, Bâtiment Géopolis, 1015 Lausanne, Switzerland, ursina.kuhn@,fors.unil.ch, +41 216923722

Gaël Brulé, University of Neuchâtel, Fbg de l'Hôpital 27, 2000 Neuchâtel, gael.brule@unine.ch

\begin{abstract}
The changes in subjective wellbeing experienced following negative life events can be buffered by various types of resources. In the present article, we compare the influences of material, religious, social and personality resources using the Swiss Household Panel (SHP) in a unified framework. Fixed effects regression models are estimated for four negative life events: separation, death of a closely related person, unemployment and disability. Buffering effects are estimated by interacting time since the event with the amount of resources. Religious resources show the strongest buffering whereas material resources do not seem to buffer consequences of negative life events. Social and personality resources present mixed results.
\end{abstract}

Acknowledgements

This study has been realized using the data collected by the Swiss Household Panel (SHP), which is based at the Swiss Centre of Expertise in the Social Sciences FORS. The project is financed by the Swiss National Science Foundation. The research was supported by the Swiss National Science Foundation (Project FNS - D-A-CH10001AL_166319).

\section{Key words}

Subjective well-being, life event, buffer, panel data, religion, personality 


\section{Introduction}

Individuals experience changing levels of subjective well-being (SWB) throughout their lifetime (Diener et al. 2003). Several theoretical frameworks have been developed to derive meaning from these findings. For instance, the setpoint theory (Lykken and Tellegen 1996) states that the level of happiness ${ }^{1}$ of individuals oscillates around a certain level, which is considered to be largely biologically driven (Lucas 2007). In that context, any gap vis-à-vis individual set-point is expected to attenuate and ultimately disappear. However, this theoretical framework has proved incapable of fully integrating recent empirical findings (Clark and Oswald 2002, Headey 2008, Anusic et al. 2014b), showing that life events such as long-term unemployment, widowhood or handicap have a long-lasting impact on happiness. These life events influence SWB not only immediately after the event, but the average level of SWB fails to return to its original level, a phenomenon known as the scarring effect. In an integrative attempt to list the effects of various life events on SWB, Luhmann et al. (2012) performed a meta-analysis using longitudinal data, which observe the reaction and adaptation to four family events (marriage, divorce, bereavement, child birth) and four work events (unemployment, reemployment, retirement, relocation/migration). The findings show a comparable pattern for the different life events (drop or increase of SWB after the event followed by a recovery process). However, the magnitude of the effects on SWB and the time of recovery differ strongly between the different events.

The more recent literature focuses increasingly on the heterogeneity in individuals' reaction to the same event. Originally emanating from stress literature (see e.g. Cohen and Wills 1985, Lazarus and Folkman 1987), a growing body of literature addresses how different resources buffer the relation between negative life events and individuals' SWB (Boyce and Wood 2011, Lechner et al. 2013, Anusic and Lucas 2014). The present article adds to this literature on buffering effects. The contribution is threefold: first, we propose an integrative and interdisciplinary framework that allows us to compare resources that are different in nature regarding their capacity to buffer negative life events. Second, we bring a contribution to the ongoing debates on the buffering effects of various resources. Third, we lay some stones in understanding the conditions for a resource to be a buffer.

In this study, we use data from the Swiss Household Panel (SHP). The Swiss context was already studied by Anusic et al. (2014) who confirmed scarring effect in the case of unemployment, widowhood and disability, but did not address buffering effects. Using fixed effects regression models, we take a longitudinal perspective that exploits variation in SWB of individuals over time. We analyze how individuals with more resources recover compared to individuals with fewer resources when facing separation, death of a closely related person, unemployment and disability. The present paper is organized as follows: section 2 presents the conceptual framework and the literature review, section 3 the data, section 4 the methods of analysis, section 5 the results, and section 6 discusses the results We conclude in section 7 .

\section{Conceptual framework and literature review}

\footnotetext{
${ }^{1}$ As commonly seen in the literature (see e.g. Diener et al. 2003) we use happiness, life satisfaction and SWB interchangeably
} 
Before reviewing the literature on buffering effects for SWB, we present the concepts at hand, namely life events and buffering effects.

\section{Life events}

The literature dedicated to the relations between life events and SWB focuses mainly on the following events: wedding, birth of the first child, separation, divorce, death of the spouse, death of a closely related person, unemployment and disability. A distinction is made between positively valenced events and negatively valenced events, also called positive life events and negative life events. Negative life events seem to have more influence than positive life events (Baumeister et al. 2001). In the present study, we focus on negative life events. The Blackwell Encyclopedia of Sociology defines stressful life events as "discrete social experiences or life changes that require individual adjustment or manifest themselves in emotional arousal or physical reactions" (Ritzer 2007).

\section{Buffering effects}

In order to grasp how individuals cope with negative life events, the processes involved in the adaptation to stressful events must be considered. Buffers ease individuals' recovery after a given event (Cummins and Nistico 2002). The buffering effects (effects that appear during and after a life event) are distinct from the main effects (direct effects of resources regardless of life events). According to the Encyclopedia of Social Psychology, a buffering effect is defined as "a process in which a psychosocial resource reduces the impact of life stress on psychological well-being" (Wills and Isasi 2007). This definition is restricted to psychosocial resources and psychological well-being. To fit the scope of our study, which is somewhat broader and interdisciplinary, a few adjustments are required. First, we do not focus only on psychosocial resources, but consider for instance also material resources. Second, we extend the definition to well-being in general. Third, we focus on discrete negative life events and not stressors. Hence, we use the term buffer for "a process in which a given resource reduces the impact of negative life events on well-being".

\section{Literature review}

The study of buffering effects is not constrained to a specific theoretical framework; buffers mitigate the variations in experienced happiness after traumatic life events, whether the recovery is complete as in the set point theory or not. Resources acting as buffers can be either internal or external (Cummins 2010). Moreover, the literature on buffering effects is wide; it is covered by the stress literature, the developmental literature and by studies on SWB (Luhmann et al. 2012). Thus, it is necessary to circumscribe a perimeter for a literature review. We discuss studies on discrete personal life events that are negative in terms of well-being. Although we focus on SWB in the empirical part, we also consider studies on psychological well-being and affective well-being even if they are not fully comparable. This enables us to have a broader view on potential buffering effects and gain some understanding, for some particular effects that are not covered when looking only at SWB. However, we do not cover the wide psychological literature on stress. We use footnotes to mention a few studies that do not fall into the scope but bring a useful light on the current blind spots of the literature. To structure the review, we grouped the different resources into four 
categories: material, religious, social and personality resources. The same structure will be used for the empirical analysis.

Material resources: material resources are defined in this study as monetary resources, either as a stock, i.e. wealth or as a flow i.e. income. According to Cummins (2000), the true power of wealth is to protect SWB by using money as a highly flexible resource that allows people to defend themselves against the negative consequences of a harmful situation. While it has been shown that income and wealth have separate direct effects on SWB (Headey et al. 2008), only one study seems to be directly tackling the buffering effect of material resources for discrete life events. This was performed by Smith et al. (2005) who showed that, in a US-American context, wealth (measured as net household financial wealth) provided a safety net that enabled quicker recovery in terms of happiness for people becoming handicapped. ${ }^{2}$

Religious resources: Religiousness is a multifaceted concept comprising cognitive, affective, behavioral, and social components, which may all be differently related to mental health and SWB (Hackney and Sanders 2003). The literature looking into the effects of religion usually distinguishes religious attendance, which is measured by the frequency of visiting a religious place or service from religiosity, which represents the self-appraisal of the level at which the respondent considers himself or herself religious (Joshanloo and Weijers 2016). Following the distinction of Cummins (2000), the former is mostly an external resource whereas the latter is rather an internal resource. Although the direct effects of religiousness on SWB have been widely studied with many interpretations given (see Lechner et al. 2013, for a review) and seem to be mainly positive (Lawler-Row and Elliott 2009), the buffering effects of religiousness on SWB for individuals facing discrete life events have rarely been assessed (Wink et al. 2005) $)^{3}$. Kidwai et al. (2014) show in a cross-sectional study in East Baltimore (USA), that, in the case of separation or disability, religious attendance and spirituality did not modify the association between negative events and affective well-being. In some rare studies, religiousness even reinforced the impact of certain family related stressors that conflict with values promoted by religious groups (Strawbridge et al. 1998).

Social resources: social support is a wide term with multiple conceptualizations. It can include different types of socialization and various levels of proximity such as family, friends, colleagues or community. Social resources are considered as external resources by Cummins and Nistico (2002). The direct positive effects of social support on happiness are largely documented (see e. g. Diener and Oishi 2005). Although acknowledged in the stress literature (see for instance Brandt 1984), the buffering effects of social resources mostly fail to find echo in studies of discrete events on SWB. ${ }^{4}$ Greene and Feld (1989) found no buffering effects of social support on happiness for women facing widowhood. Neither did Doeglas et al (1994) on psychological well-being in the case of disability. A study of

\footnotetext{
${ }^{2}$ Martikainen and Valkonen (1998) studied the mortality of widows after experiencing bereavement and found no clear buffering effect of income.

${ }^{3}$ Some studies have covered non-discrete events. Lechner et al. (2013) found that both religious attendance and subjective religiosity buffered the impact of work-related demands on depressive symptoms but not on life satisfaction or work satisfaction.

${ }^{4}$ For social support and stressors, see e.g. Cummins (1990) for job stressors, Laudet et al. (2005) for drug addiction, Mueller (2006) for couple difficulties.
} 
Neugebauer and Katz (2004) shows no moderating effect of emotional support on affective well-being after individuals became disabled. A study by Anusic and Lucas (2014) examining the effect of social support on widowhood in three longitudinal datasets (GSOEP, BHPS, HILDA) is the closest to our approach. The analysis revealed no buffering effect of social support on life satisfaction. In contrast to the direct effects of social support on happiness, there is so thus no empirical evidence for buffering effects for SWB. This is in line with a study by Kornblith et al. (2001), who analyzed the effects of social support as a buffer for stressful events. The study found that life events and social support have independent effects on the emotional state (additive model), rather than social support mitigating the influence of life events on the emotional state (buffering model).

Personality resources: personality often refers to individual differences in characteristic patterns of thinking, feeling and behaving. Personality is considered as an internal resource (Robb et al. 2008). In the literature, it is usually measured by the Big Five personality traits (openness to experience, conscientiousness, extraversion, agreeableness, and neuroticism) developed by Costa and McCrae (1992). Although there is a rather clear consensus around the main effects of personality on happiness ${ }^{5}$ (see for instance Ford et al. 2016), studies looking into the buffering effects fail to show a clear picture. Boyce and Wood (2011) suggest that agreeableness is associated with more complete adaptation of life satisfaction to disability. Moreover, highly conscientious people seem to be more affected by unemployment than their less conscientious counterparts (Boyce et al. 2010). These findings failed to be replicated with other data. Yap et al. (2012), Anusic et al. (2014a) and Pocnet et al. (2016) show no particular buffering effects of the Big Five personality on the respondents' SWB to major life events such as widowhood or unemployment.

Summing up the literature on buffering effects of various resources on SWB, one can observe several shortcomings. First, although the effects of different life events have been considered within the same meta-study (e.g. Luhmann et al. 2012) or various coping strategies towards life events have been compared (Satija et al. 1998), the buffering effects of various resources on SWB have, to our knowledge, never been compared. Rather, most studies focus on one resource and one event. Second, the measures and the scales related to well-being are almost as numerous as the number of studies. Third, the different types of data and statistical methods complicate the comparison of different resources and events across studies further. Finally, evidence about these effects are mixed: although the main effects of these resources seem to be indisputable, the presence of buffering effects either fail to gather any consensus (e.g. personality or religiousness) or are tackled in too few studies or in studies that are too different to observe any pattern (e.g. wealth). This fragmentations and lack of standardization makes it virtually impossible to compare the relative importance of the buffering effects of the different resources presented above. The heterogeneity of the studies can partly be explained by epistemological reasons and academic specialization: although cross-fertilization of disciplines exists, wealth is mostly a resource of choice for economists, social support and religiousness for sociologists, personality for psychologists. Although these resources are intrinsically different, they can be compared if one is to adopt a utilitarian perspective and look at the effects after negative life events.

\section{Study design and data}

The goal of the present paper is to shed an integrative and comparative light on buffering effects identified in the literature and thus to partially tackle the identified shortcomings. We study the effects of various resources present in the literature holding life events, the measure of well-being, the data source and the method of analysis constant. The

\footnotetext{
${ }^{5}$ Among personality traits, extraversion and neuroticism are usually found to predict happiness best.
} 
main objective of the study is to compare the capacity of different resources to buffer negative life events. The detailed explanation of the mechanism for each resource and event falls out of the scope of the present work. A secondary objective is to offer a new light on the effects that fail to gather consensus, either because of existing disagreements (e.g. personality traits) or because too few studies exist, as in the case of wealth.

\section{Data}

We use data of the Swiss Household Panel (SHP), an ongoing household and person survey, which started in 1999 and is representative for the Swiss residential population. Data is collected through yearly telephone interviews (CATI). The initial sample in 1999 included 7,799 individuals from 14 years on (from 5,074 households). Refreshment samples were added in 2004 (2,538 households and 3,645 individuals) and 2013 (3,989 households and 6,090 individuals). These individuals and all members of their households are followed over time. In 2016 the original sample still contained 2,700 households (4,311 individuals). The second sample still included 1,277 households (1,909 individuals), and the third sample 2,425 households (3,809 individuals). In total, 28,101 individuals have ever responded to the individual questionnaire. Details on the study design, response and attrition can be found in Tillmann et al. (2016).

\section{Variables}

As a measure of SWB, we use overall satisfaction with life, measured on an 11-point scale. The question is the following: "In general, how satisfied are you with your life, if 0 means 'not at all satisfied' and 10 means 'completely satisfied'?". This is a well-established measure validated by various studies. By focusing on cognitive well-being rather than on affective well-being, effects of life-events on well-being should be stronger (Luhmann et al. 2012). In the rest of the study we focus on life satisfaction.

As life events, we select discrete negative life events that are present in the literature and that are experienced by a sufficient number of individuals in the SHP. This means we leave out continuous events such as illness that would make the identification of the time of the event and the recovery harder. Four events qualify for this study: separation, death of a closely related person, unemployment and disability.

Table 1 about here

Table 1 explains the details of the coding for the four events. Individuals may have experienced multiple. The rarest event is disability $(\mathrm{N}=845)$. Separation $(\mathrm{N}=1,066)$ and unemployment $(\mathrm{N}=1,288)$ are somewhat more frequent. Death of a closely related person $(\mathrm{N}=29,017)$ is by far the most common event studied here. This has consequences for the statistical analysis, as the same effect size is more likely to appear significant for events that are more frequently experienced. It is therefore crucial to take account of the effect sizes of the different models.

We selected four types of resources broken down into 13 items: material resources (wealth and income), religious resources (religious attendance, feeling religious, feeling spiritual), social resources (emotional support, number of 
friends, frequency of contact with friends) ${ }^{6}$ and personality resources (conscientiousness, openness, agreeableness, extraversion, neuroticism). The measurement and coding of each resource is described in Table 2 in detail. Because we include buffering effects as interactions into our models, we measure each resource either as a dichotomous (two groups) or continuous variable to limit the complexity of the model. Moreover, we standardize continuous variables, so that each resource is coded within the range of 0 to 1 . The question wordings for all variables and descriptive statistics of the variables are listed in the appendix.

Table 2 about here

According to our definition, buffers facilitate the recovery after negative life events. However, a given event may impact the resource itself. For example, the death of a closely related person will directly impact the personal network or might increase religious attendance. In this study, we are interested in the protective potential of resources, rather than in the variability of resources over time. We therefore construct the resources as time-invariant variables per event. ${ }^{7}$ Preferably, the amount of resources is measured before the occurrence of the event to assure that the resources are not endogenous to the event. As the resources measured shortly before the event might be influenced by anticipation of the event, we chose two years before the event as the preferred measurement point for resources. This point is relatively close to the event, but unlikely to be affected by anticipation effects. However, in some cases, the buffering variable has not been measured two years before the event either because of non-response, because the question has not been asked in the respective wave, or because the individual was not yet in the sample. We use a sequential procedure to reduce the number of missing values. If possible, we rely on previous measures (from three or more years before the event are available). If no earlier measure is available, we substitute missing resources with measures from one year before the event. However, variables for certain resources (wealth, religious feelings, spiritual feelings, personality) have only been collected in recent years (see Table 2), so that we do not have sufficient cases that were measured before the event. These resources are measured either before or after the event, but held stable for each individual and event.

\section{Sample selection}

We carry out separate analysis for each event and each buffer, which means that we have 52 different regression models (4 events, 13 resources). The analytic sample for each model is composed of individuals who have experienced the selected event during one of the available panel waves, for whom we know the year of occurrence of the event, and for whom we measured the level of the resource. We analyse data from two years before the event $(\mathrm{t}=-$

\footnotetext{
${ }^{6}$ There has been a change in the questionnaire. The yearly questions on relatives (available from 1999-2010) has been replaced by separate questions for children, father, mother, siblings and other relatives every three years (in 2013 and 2016). This is why we selected friends as indicators. However, using an alternative measure for the entire network gives similar empirical results. The change in the questionnaire concerns also the measure of emotional support (see appendix).

${ }^{7}$ If there are multiple events, the buffer variable may vary between the events.
} 
2) to two years after the event $(\mathrm{t}=2) .{ }^{8}$ The number of cases varies strongly between models, depending on the event and the resource studied (between 418 and 10,431 individuals).

\section{Framework of analysis}

Due to the diversity of resources, events and the mixed results in literature, we do not formulate explicit hypotheses. Rather, we use several classifications to structure the interpretation of empirical results. First of all, we distinguish work-related events (disability, unemployment) and family-related events (separation, death of a close person). Another difference is that we consider death and disability as more exogenous than separation and unemployment, which can be at least partially influenced by individual choices. Moreover, we distinguish internal resources (personality ${ }^{9}$, feeling religious, feeling spiritual) from external resources (material resources, social resources, religious attendance).

\section{Methods of analysis}

Fixed-effects (FE) regressions are performed to assess the differences between the two groups for the selected events and buffering resources. The dependent variable is life satisfaction. As independent variables, we include the level of resources and time to event. Time is measured by 5 dummy variables: two waves before the event $(\mathrm{t}=-2)$, one wave before the event $(\mathrm{t}=-1)$, first wave after the event $(\mathrm{t}=0,0-12$ month after the event), second wave after the event $(\mathrm{t}=1$, 12-24 month after the event), third wave after the event $(\mathrm{t}=2,24-36$ month after the event). The resource variable either distinguishes two groups or is continuous and scaled to values between 0 and 1 . Buffering effects are measured by interacting time to event and the resource variable.

FE regressions exploit the change in life satisfaction over time and do not compare the level of life satisfaction of different groups of individuals (main effects) (see Clark et al. 2008 for a more detailed description of the approach). To measure buffering effects, we compare life satisfaction after the event to the level two years before the event (reference category). ${ }^{10} \mathrm{We}$ do not discuss the impact shortly after the event $(\mathrm{t}=0)$, but focus on the longer-term adaptation at least 12 month after the event $(\mathrm{t}=1$ and $\mathrm{t}=2)$. The interaction coefficient between a given resource and the years after a given shows the buffering effect of the resource. A positive buffering effect occurs if individuals with many resources have a smaller drop in life satisfaction than individuals with few resources (compared to two years before the event). However, a significant negative interaction coefficient indicates an aggravating effect rather than a buffering effect.

\footnotetext{
${ }^{8}$ In case of multiple events, we exclude some observations between two events. This concerns observations that are one or two years after an event and, at the same time, one year before the next event.

${ }_{9}^{9}$ Although conceptually internal, personality includes in addition to an internal component (intra-individual components, i.e openness, conscientiousness and neuroticism) a rather external component (interindividual components, i.e. agreeableness and extraversion)

${ }^{10}$ The buffering variables are stable for each event. In cases with multiple events per individuals, the buffer variables might change over time for the same individual. These models include not only an interaction, but also a main effect for the buffering variables.
} 
It has to be noted that the power of the presented analysis is limited even if a considerable number of individuals (at least 845) experienced the events. Firstly, not all resources could be measured for all individuals. Especially, information on psychological resources is often missing, because they were measured only in 2015. Second, not the entire sample that experienced the event is still observed one and two years later. For example, among the 1,075 individuals who experienced a separation, only a subsample is still observed and separated in the following years $(\mathrm{n}=758$ at $\mathrm{t}=1, \mathrm{n}=537$ at $\mathrm{t}=2$ ). A considerable buffering effect is therefore necessary to obtain a significant interaction effect. Third, the measurement of interaction effects is more demanding on sample size than main effects. Finally, also the estimation of FE models requires a relatively large sample (see e.g. Bollen and Brand 2010). This is, because only a small part of variation of variables (only the variance within individuals) is exploited in the model.

Due to these power considerations and in order to compare the different regression models, we include only time dummies and the level of resources into the model. To assure comparability of the models, we do not include eventspecific control groups of individuals who did not experience the event either. Control variables and control groups are crucial to estimate main effect of life events, but are less important for buffering effects, which are the focus of this study.

Considering that we test buffering effects of 13 different resources, the type I error rate is increased by multiple testing. As a sensitivity analysis, we have therefore also used an alternative procedure that takes account of repeated comparisons (Benjamini and Hochberg 1995). Although there were a few differences for effects that are close to the level of significance, both methods identify the same buffering effects and do not affect the main conclusions. ${ }^{11}$ The repeated testing presents an additional reason (besides the variation in sample sizes) to focus not only at the significance level but also at the effect size.

\section{Empirical results}

\section{Overview of the results}

The regression coefficients of the buffering effects are presented in Table 3, which shows the interaction term of the buffering variable with the time variable (one and two years after the event compared to two years before the event). The complete results of the 52 regression models are presented in the Appendix. The coefficient shows how the drop in life satisfaction differs between individuals with higher resources and individuals with lower resources. The coefficients can be interpreted in terms of changes in life satisfaction. A positive coefficient indicates a buffering effect of the resource studied and means that individuals with high resources have experienced a smaller drop in life satisfaction than individuals with lower resources. A negative coefficient implies that the resource considered does not buffer the negative effects of the event, but rather reinforces the drop in life satisfaction. Because these

\footnotetext{
${ }^{11}$ The Benjamini-Hochberg procedure controls the proportion of significant results that are misleadingly positive. For the analysis, we defined 13 repeated measures and a false discovery rate of 0.2 following the recommendations by McDonald (2014). Three aggravating effects, that are significant at a $0.05 \mathrm{p}$-value, are not significant according to the Benjamini-Hochberg procedure. In contrast, two additional aggravating effects become significant. Both methods identify the same significant buffering effects.
} 
coefficients refer only to the interaction term and not to the main effect, a negative coefficient does not mean that the resource is detrimental per se for life satisfaction.

Table 3 about here

The number of significant buffers changes according to the event: disability and unemployment are the most buffered while death of a closely related person and separation appear the least buffered. The effect sizes of the significant variables are considerably smaller for death of a closely related person (significant effect are 0.1 points in life satisfaction or stronger) compared to the other events (at least 0.5 points in life satisfaction). This can be explained by the much higher sample size in the case of death. The strongest buffering effects are observed in the case of disability (1.5 points in life satisfaction for agreeableness), and in the case of unemployment, where those with higher religious attendance lose 0.8 points less in life satisfaction than those with lower religious attendance. The strongest aggravating effect is also found for unemployment, where the most neurotic individuals lose 2.1 points more in life satisfaction than the least neurotic individuals. It should also be noted that the coefficients have a different meaning for continuous resource variables (wealth, income, number of friends, contact with friends, personality measures) than for dichotomous variables. For the former, the interaction compares the maximum and minimum level of resources. For the later, the interaction compares the two groups. It is therefore possible to compare effect sizes of different events, but not of different resources. Although each event is somewhat influenced by some of the resources considered in the study, one needs to look at each interaction in order to provide some elements of understanding. Some significant effects are illustrated graphically to depict the evolution for two groups (with high and low resources) for a given resource. After a brief overview of the findings, we discuss the results by type of resource in more detail.

Results per type of resource

Material resources: wealth and income do not show any buffering effects for the events considered. However, there are two aggravating effects. Wealthy individuals facing separation recover more slowly than less wealthy individuals. Similarly, high income individuals experience take longer to adapt to a of death of a closely related person (cf. Figure 1). 
Fig. 1

Predicted life satisfaction for different life events and material resources
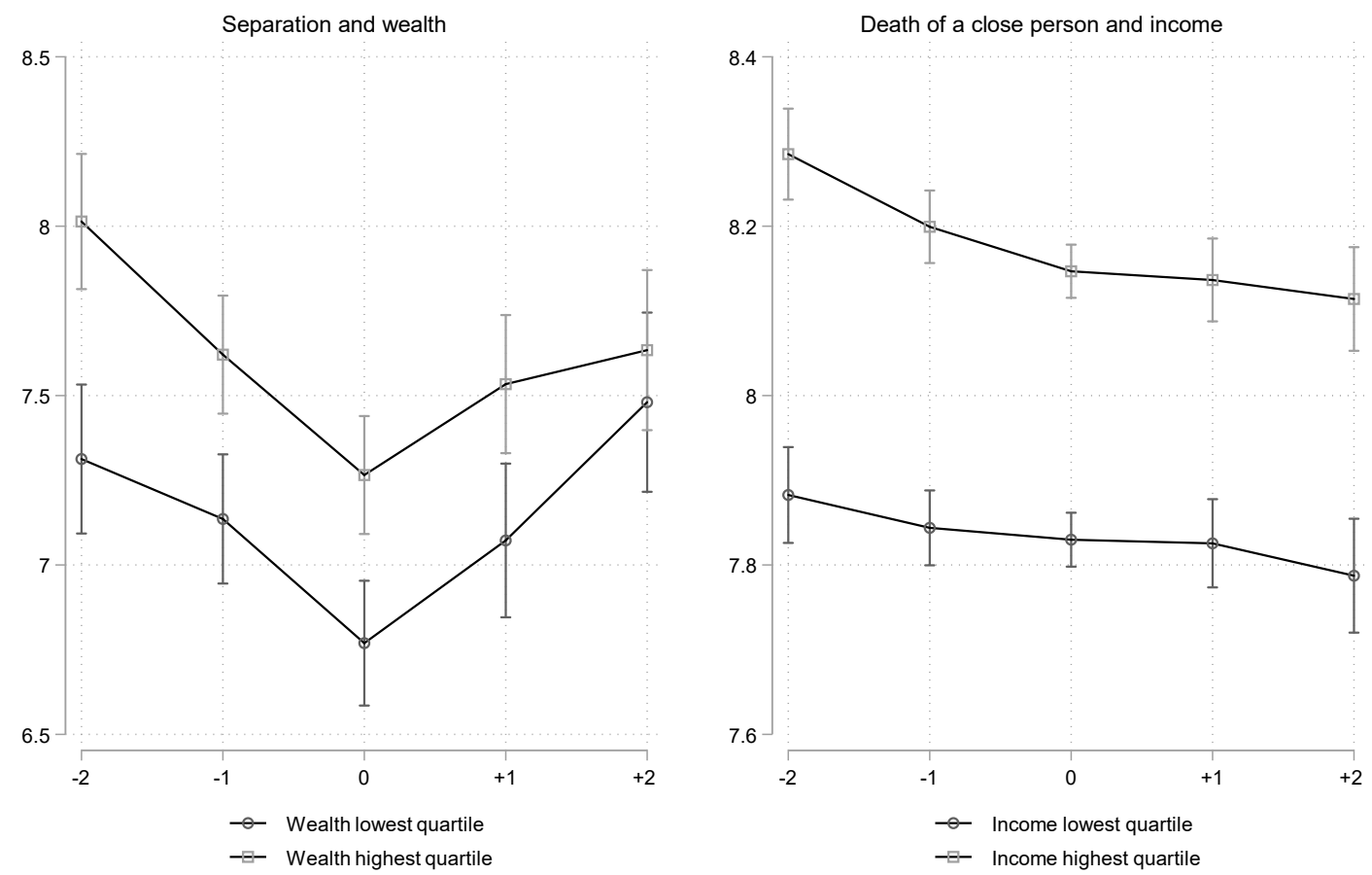

Note: The buffering effects are assessed by comparing predicted life satisfaction one and two years after the event to life satisfaction two years before the event. Y-scales are model-specific. Source: SHP 1999-2016.

Religious resources: religious resources present a rather consistent picture: this type of resource offers a buffering effect in the case of a death of a closely related person, unemployment and disability and an aggravating effect in the case of separation (cf. Figure 2). 
Fig. 2

Predicted life satisfaction for different life events and religious resources


Note: The buffering effects are assessed by comparing predicted life satisfaction one and two years after the event to life satisfaction two years before the event. Y-scales are model-specific. Source: SHP 1999-2016.

Social resources: only one buffer effect appears in the case of emotional support and unemployment. Moreover, the item 'number of friends' seems to have a negative effect for death of a closely related person, unemployment and disability. In the case of death of a closely related person, every item is negatively related to change in life satisfaction (cf. Figure 3). 
Fig. 3

Predicted life satisfaction for different life events and social resources
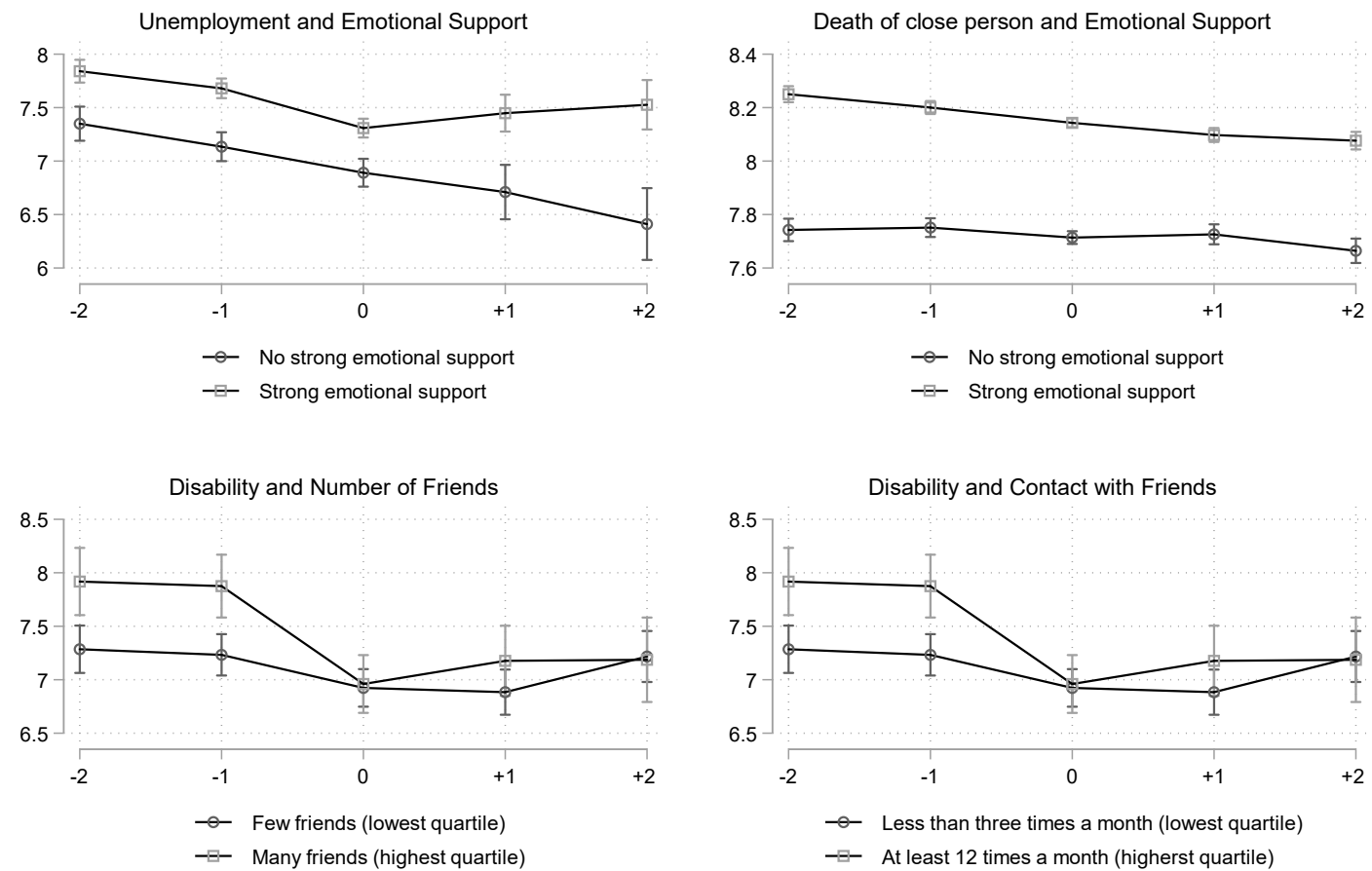

Note: The buffering effects are assessed by comparing predicted life satisfaction one and two years after the event to life satisfaction two years before the event. Y-scales are model-specific. Source: SHP 1999-2016.

Personality resources: personality items show scarce effects for the various events considered. The most consistent effect is the negative effect of neuroticism on individuals' SWB in the case of death of a closely related person and unemployment (cf. Figure 4 for unemployment). Agreeableness is a buffer in the case of disability. 
Fig. 4

Predicted life satisfaction for different life events and personality resources
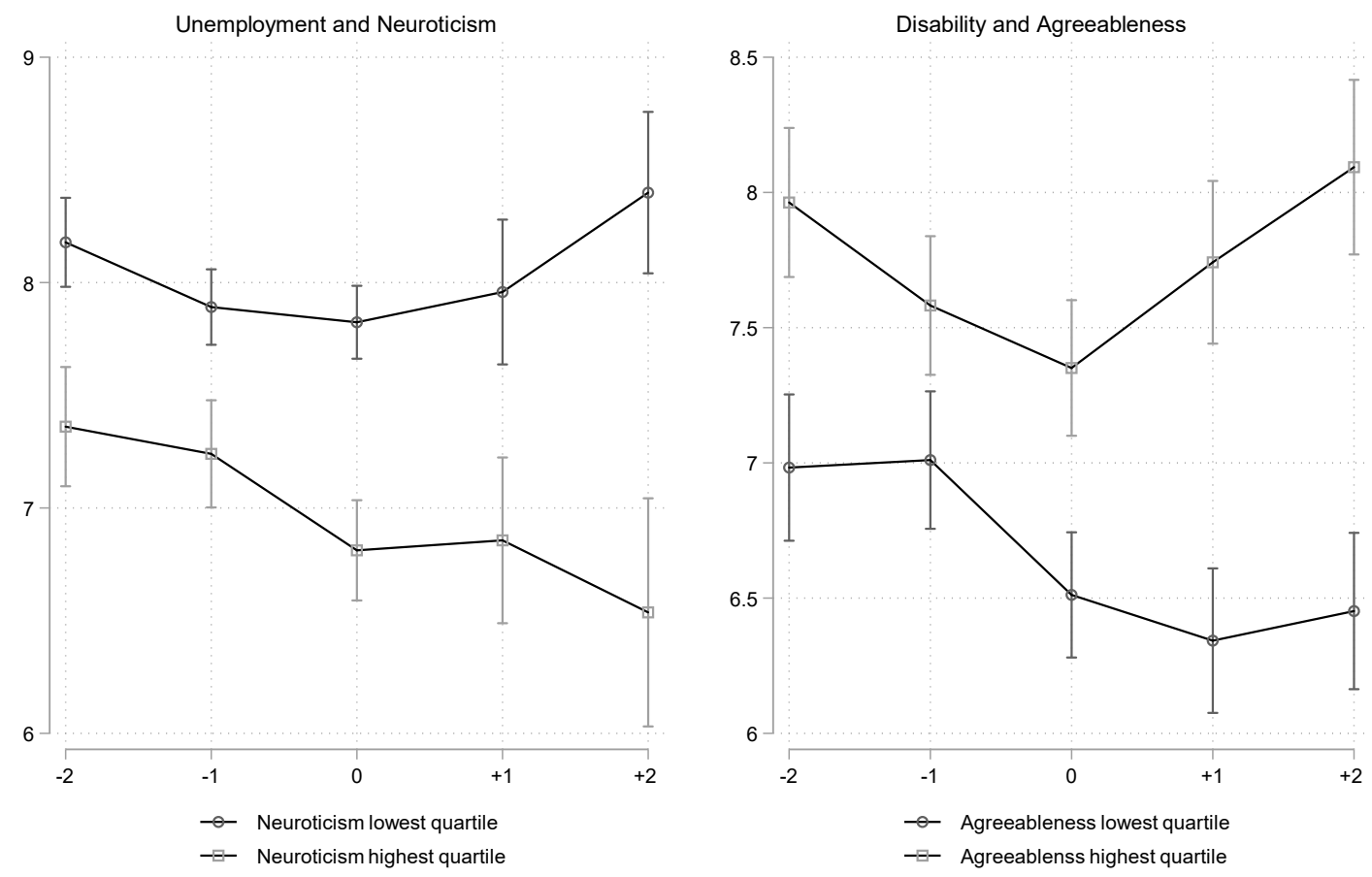

Note: The buffering effects are assessed by comparing predicted life satisfaction one and two years after the event to life satisfaction two years before the event. Y-scales are model-specific. Source: SHP 1999-2016.

\section{Discussion}

The two work-related effects (disability and unemployment) are more buffered by the various resources than the two family related events (separation and death of a closely related person). Moreover, family-related events show some aggravating effects. However, due to the contrasted picture of the effects per type of resource, focusing on the events without looking at the nature of the resource at hand cannot provide a satisfactory framework. It is necessary to look into more details at the specific interactions between events and resources.

\section{Material resources}

In this study, material resources, whether in the form of wealth or in the form of income, did not buffer the effects of life events. Possibly, buffering is not captured through this sample size and particular dataset. One could imagine that material resources would make unemployment less stressful and disability easier to cope with. Yet, this is not what we observe. A possible explanation can be found within the Swiss context, where the protective social security system may alleviate financial strain after these events. It should also be kept in mind that our study focuses on 
resources as a stable characteristic and we do not analyze how wealth or income is changed by the event. In the case of death of a closely related person, high-income earners even experience a more substantial drop than low-income individuals. We observe the same pattern for high wealth individuals who experience a longer lasting drop in life satisfaction following separation. A rather "mechanical" explanation is that high income earners have a higher level of happiness and therefore more to lose. For instance, those with higher income might have a more brutal loss in terms of income or meaningful activity following disability. ${ }^{12}$ As for high wealth people, possible quarrels and dissatisfaction around sharing can only occur for those who have something to share. In that regard, one can understand that in spite of positive main effects of income and wealth, these resources can somewhat become a burden in harsh times.

\section{Religious resources}

Although religious resources appear as the most frequent buffer, they are not universal as can be observed in the case of separation. One could think that social support is what matters the most in attending religious services. When comparing with the effects of social support, one has to revise and refute that hypothesis. The significant and strong effects of religious and spiritual feelings show that there is more to religion than the social network. The benefits of religion seem to be related to feeling religious and making sense of encountered difficulties when facing an uncontrollable event. This buffering function of religion is partly in line with what was observed by early $20^{\text {th }}$ century sociologists. Spiritual and religious practices offer a transcendental time that Emile Durkheim calls "sacred time", a time apart from the "profane time" that individuals live most of their lives in. Weber (1963) refers to the religious needs as "the metaphysical necessities of the spirit". Religion makes it possible to make sense ex post of the events that the individual is facing and to rebuild (nachbilden) these reasons. In that sense, Weber shows the rationality there is in attending church and of religious beliefs as attested by the frequency of use of terms such as Rationalisierung or Durchrationalisierung in his writings about religion.

A leaning toward traditional values might bring a religious or moral sanction together with the separation. A stable relationship is highly valued by most religious groups and separation is often condemned by explicit or tacit rules. In that context, religion acts as an aggravator, making things temporally worse for the given person. ${ }^{13}$ This is somewhat in line with Strawbridge et al. (1998) who show that in some cases, religion could have aggravating effects when the event studied was against the norms conveyed by religious groups. A person recently separated might suffer not only from the separation but also for not living according to the social norms in his or her environment, whereas the person attending religious services less frequently would feel less stigmatized. This is congruent with the fact that the only item which acts as an aggravator during separation is 'religious attendance', and not 'feeling religious' or 'feeing spiritual'.

\footnotetext{
${ }^{12}$ Due to our coding, we only analyze individuals who become unable to work for reasons of disabilities. Disabilities, where individuals remain economically active are not captured. Still, income could buffer this drop and this is not the case.

${ }^{13}$ Two years after separation however, individuals with frequent religious attendance do not suffer significantly more strongly from separation than individuals with no or rare religious attendance.
} 


\section{Social resources}

The various items respond differently to the life events considered, which confirms that social support is not a unidimensional concept (Costanza et al. 1988). These effects appear both negative and positive, a phenomenon also observed by Calicchia and Graham (2006) who showed that, depending on the context, a given resource can be both a support or a stressor. Only one positive effect can be observed: emotional support helps coping with unemployment. Next, a few patterns emerge. First, social resources have no significant effect in the case of separation. Possibly, the pros and cons of each item counterbalance each other. For instance, having social support can be of great help to prevent depression, but can also be a burden during a transitional phase. Further, the network is more important for individuals with many friends than for individuals with fewer close friends, both in terms of contact and in terms of image. Any loss in that network, e.g. by losing an important person in the case of bereavement or by losing professional contacts in the case of unemployment and disability would degrade life satisfaction more strongly for people for whom the personal network is important.

Finally, it is rather striking that not only the number of friends, but also emotional support and the frequency of contact with friends seem to reinforce the negative effects following the loss of a closely related person. People with these forms of support experience a longer lasting drop in life satisfaction compared to their less social counterparts, even if the effect is modest (drop in life satisfaction is 0.1 points stronger one year after the event). A first reason is that some of the people reporting the most social support may have lost their most cherished person. In that sense, as in the case of high income and high wealth individuals, this group of higher support has more to lose in terms of social support. A possible related explanation is that this group of pro-social people typically experience higher levels of happiness and they simply drop from a higher level, as can be seen in Figure 2. Accordingly, the potential impact of bereavement is lower for those who have already a lower life satisfaction because they lack social support even before the occurrence of the event. More fundamentally, bereavement has been called a "social network crisis" (Stylianos and Vachon 1993). Rook (1984) significantly contributed to the investigation of the negative sides of social interaction. These undesired secondary effects can be of several natures, such as such as overprotection, loss of self-esteem or bad relationships. In the case of social support for the elderly, Sakata (1997) writes that there "may be unfavorable forms of support, for example, overprotection, reinforcement of health-damaging behavior, or assistance given on demanding and debilitation terms" (p.31). Depending on the cases, the adjustment process of individuals can be improved (e.g., intimate relationships) or impeded (e.g., dependency-sustaining relationships). The possible negative effect of close friends during bereavement is explicitly stated by Van Baarsen (2002): "the presence of close friends, however, seemed to increase emotional and social loneliness (i.e., decrease perceived support) in the long term, particularly among bereaved participants with lower self-esteem."

\section{Personality resources}

The negative influence of neuroticism in case of death of a closely related person and unemployment (cf. Figure 4) can easily be explained, as the tendencies to respond with negative emotions to threat, frustration, or loss are part of the very definition and operationalization of neuroticism. The difficultly in coping with difficult events for neurotic 
individuals has been shown elsewhere (see e.g. Taylor and Stanton 2007). Neurotic individuals might have more troubles when facing a difficult event. While these reactions have been proved in the case of depression, we show here effect of this trait on SWB. Regarding disability, the only personality item that positively matters is agreeableness (cf. Figure 4). This personality trait is related to the development of harmonious relationships with others, which could explain why this helps individuals recovering better. Furthermore, some effects are large but not significant at the $5 \%$ level due to the relatively small sample size for personality resources. This concerns a negative effect for agreeableness in the case of separation (effect of -1.1 at $t=2, n=618$ ) and conscientiousness in the case of unemployment (effect of -1.0 at $\mathrm{t}=1, \mathrm{n}=639$ ). It will be worth testing these influences with larger samples. The negative effect of conscientiousness in the case of unemployment is in line with what has been reported by Boyce et al. (2010) as the "dark side of conscientiousness". Finally, Yap et al. (2012) do not find any buffering effect of personality traits on widowhood and unemployment. The present study is in line with these findings as far as extraversion and openness are concerned.

\section{What makes a resource a buffer?}

The unified framework makes possible a reflection upon the circumstances under which a given resource acts as a buffer. Resources that help individuals to cope with negative life events seem to be mostly internal, have no undesirable effects and to be not directly affected by the event. First, the predominant positive effect of internal resources versus external resources seems to indicate that coping is mostly internal and mostly derived from spiritual or positive attitudes. As depicted by the spirituality resource, it seems to be a matter of how to integrate a hurtful event into a new meaningful framework. In contrast, external resources, such as income, wealth or the social network mostly fail to ease the recovery of adverse events in spite of main (positive) effects reported in the literature. Second, resources might be particularly helpful for some events but have undesirable effects on others. For example, religion buffers the consequences of the loss of a closely related person, unemployment and disability, but, in the case of religious attendance, has adverse effect on separation. Similarly, emotional support seems to help in the case of unemployment, but not in the case of death of a close person. Therefore, resources cannot be simply tagged as 'positive' or 'negative' but need to be contextualized. Finally, limited buffering effect or even aggravating can occur if the resource itself is affected by the event. For instance, the loss of a closely related person, will likely result in losses in the intimate network and entail a 'social network crisis'. People with a dense social network experience a higher drop than people that are less socially active. Generally speaking, the category of people with more resources always has more to lose.

\section{Conclusion}

This study estimated buffering effects of various resources for four different negative life events. Rather than studying levels of well-being, we take a longitudinal perspective and analyze how SWB changes following the events. Religion-related items show the most buffering, except in the case of separation, where religious attendance has a negative effect. Material resources are not able to buffer the events studied here. Results for the buffering effects of social resources are mixed. Finally, in terms of personality traits, few effects appear for neuroticism and 
agreeableness. Overall, we find that internal resources are more helpful for individuals to recover from negative life events than external resources such as income, wealth and the social network.

We observe the drop and recovery in life satisfaction not as a mere product of external consequences but rather as discrepancies between external conditions and individual resources. If one cannot prevent the various events studied in this study to happen, being aware of the resources that facilitate the recovery, can help to protect the resources that matter in communities and societies. As pointed out by Cassel (1976, p.121) in the case of social support, "it seems more feasible to attempt to improve and strengthen [the social supports] rather than reduce the exposure to stressors." At the same time, our results suggest that external resources, which are the most variable over time and the most influenceable - such as material resources or the social network - do not help to recover from negative life events. The resources which show the strongest buffering effects are deeply rooted in persons and rather stable over time, such as the personality or spirituality. This entails that for individuals, and even more so for policymakers, direct interventions for a better protection against the negative consequences of the life events studied are difficult. Knowledge on the buffering effects can however help to better understand the heterogeneity in reactions to negative life events and to identify vulnerable persons in this respect.

In order to push further the current analyses and to possibly increase significance of certain effects, future work requires larger datasets that can include additional control variables, address the interrelation of the different resources and study the effect of experiencing multiple events. Moreover, future work could test whether and how the event impacts the resources themselves. 


\section{References}

Anusic, I., \& Lucas, R. (2014). Do social relationships buffer the effects of widowhood? A prospective study of adaptation to the loss of a spouse. Journal of Personality, 82(5), 367-78.

Anusic, I., Yap, S., \& Lucas, R. (2014a). Does personality moderate reaction and adaptation to major life events? Analysis of life satisfaction and affect in an Australian national sample. Journal of research in personality, 51, 6977.

Anusic, I., Yap, S., \& Lucas, R. (2014b). Testing Set-Point Theory in a Swiss National Sample: Reaction and Adaptation to Major Life Events. Social Indicators Research, 119(3), 1265-1288. http://doi.org/10.1007/s11205-013$0541-2$

Baumeister, R. F., Bratslavsky, E., Finkenauer, C., \&, Vohs, K. D. (2001). Bad is stronger than good. Review of General Psychology, 5(4), 323-370.

Benjamini, Y., \& Hochberg, Y. (1995). Controlling the false discovery rate: a practical and powerful approach to multiple testing. Journal of the Royal Statistical Society, 57(1), 289-300.

Bollen, K. A., \& Brand, J. E. (2010). A General Panel Model with Random and Fixed Effects: A Structural Equations Approach. Social Forces, 89 (1), 1-34. https://doi.org/10.1353/sof.2010.0072.

Boyce, C. J., \& Wood, A. M. (2011). Personality prior to disability determines adaptation: Agreeable individuals recover lost life satisfaction faster and more completely. Psychological Science, 22, 1397-1402.

Boyce, C. J., Wood, A. M., \& Brown, G. D. A. (2010). The dark side of conscientiousness: Conscientious people experience greater drops in life satisfaction following unemployment. Journal of Research in Personality, 44, 535539.

Brandt, P. A. (1984). Stress-buffering effects of social support on maternal discipline. Nursing Research, 33(4), 229234.

Brulé, G., \& Maggino, F. (2017). Towards more complexity in subjective well-being studies. In Brulé, G. \& Maggino, F. (Eds). Metrics of subjective well-being: limits and improvements (pp. 1-17). Dordrecht: Springer.

Calicchia, J. A., \& Graham, L.B. (2006). Assessing the Relationship between Spirituality, Life Stressors, and Social Resources: Buffers of Stress in Graduate Students. North American Journal Of Psychology, 8(2), 307-320.

Cassel, J. (1976). The contribution of the social environment to host resistance. American Journal of Epidemiology, 104(2), 107-22. 
Clark, A. E., \& Oswald, A. J. (2002). A simple statistical method for measuring how life events affect happiness. International Journal Of Epidemiology, 31(6), 1139-1144.

Clark, A. E., Diener, E., Georgellis, Y., \&. Lucas, R. E. (2008). Lags And Leads in Life Satisfaction: A Test of the Baseline Hypothesis. The Economic Journal, 118 (529), F222-43.

Cohen S., \& Wills T. A. (1985). Stress, social support, and the buffering hypothesis. Psychological Bulletin, 98(2), $310-57$.

Costa, P. T. Jr., \& McCrae, R. R. (1992). Revised NEO Personality Inventory (NEO-PI-R) and NEO Five-Factor Inventory (NEO-FFI) manual. Odessa, FL: Psychological Assessment Resources.

Costanza, R. S., Derlega, V. J., \& Winstead, B. A. (1988). Positive and negative forms of social support: Effects of conversational topics on coping with stress among same-sex friends. Journal Of Experimental Social Psychology, 24(2), 182-193.

Cummins, R. A. (1990). Job stress and the buffering effect of supervisory support. Group and Organizational Studies, 15(1), 92-104.

Cummins, R. A. (2000). Personal income and subjective well-being: A review. Journal of Happiness Studies, 1(2), $133-158$.

Cummins, R. A. (2010). Subjective Wellbeing, Homeostatically Protected Mood and Depression: A synthesis. Journal of Happiness Studies, 11(1), 1-17.

Cummins, R. A., \& Nistico, H. (2002). Maintaining life satisfaction: The role of positive cognitive bias. Journal of Happiness Studies, 3(1), 37-69.

Diener, E., Oishi, S., \& Lucas, R. E. (2003). Personality, culture, and subjective well-being: Emotional and cognitive evaluations of life. Annual Review of Psychology, 54, 403-425.

Diener, E., \& Oishi, S. (2005). The nonobvious social psychology of happiness. Psychological Inquiry, 16, 162-167.

Doeglas, D., Suurmeijer, T., Krol, B., Sanderman, R., van Rijswijk, M., \& van Leeuwen, M. (1994). Social support, social disability, and psychological well-being in rheumatoid arthritis. Arthritis \& Rheumatism, 7, 10-15.

Ford, T. E., Lappi, S. K., \& Holden, C. J. (2016). Personality, Humor Styles and Happiness: Happy People Have Positive Humor Styles. Europe's Journal of Psychology, 12(3), 320-337.

Greene, R. W., \& Feld, S. (1989). Social support coverage and the well-being of elderly widows and married women. Journal of Family Issues, 10(1), 33-51. 
Hackney, C. H., \& Sanders, G. S. (2003). Religiosity and mental health: A meta-analysis of recent studies. Journal for the Scientific Study of Religion, 42, 43-55.

Headey, B. (2008). Life Goals Matter to Happiness: A Revision of Set-Point Theory. Social Indicators Research, $86(2), 213-231$.

Headey, B., Muffels, R. \& Wooden, M. (2008). Money Does Not Buy Happiness: Or Does It? A Reassessment Based on the Combined Effects of Wealth, Income and Consumption. Social Indicators Research, 87(1), 65-82.

Joshanloo, M., \& Weijers, D. (2016). Religiosity moderates the relationship between income inequality and life satisfaction across the globe. Social Indicators Research, 128(2), 731-750.

Kidwai, R., Mancha, B. E., Brown, Q. L., \& Eaton, W. W. (2014). The effect of spirituality and religious attendance on the relationship between psychological distress and negative life events. Social Psychiatry and Psychiatric Epidemiology, 49(3), 487-497.

Kornblith, A. B., Herndon, J. E., Zuckerman, E., Viscoli, C. M., Horwitz, R. I., Cooper, M. R., et al. (2001). Social support as a buffer to the psychological impact of stressful life events in women with breast cancer. Cancer 91, 443454.

Laudet, A., Morgen, K., \& White, W. (2006). The Role of Social Supports, Spirituality, Religiousness, Life Meaning and Affiliation with 12-Step Fellowships in Quality of Life Satisfaction among Individuals in Recovery from Alcohol and Drug Problems. Alcohol Treatment Quarterly, 24(5-6), 33-73.

Lawler-Row, K.A., \& Elliott, J. (2009). The Role of Religious Activity and Spirituality in the Health and Well-being of Older Adults. Journal of Health Psychology 14(1), 43- 52.

Lazarus, R. S., \& Folkman, S. (1987). Transactional theory and research on emotions and coping. European Journal of Personality, 1(3), 141-169.

Lechner, C. M., Tomasik M. J., Wasilewski, J., \& Silbereisen, R. K. (2013). Exploring the stress-buffering effects of religiousness in relation to social and economic change: evidence from Poland. Psychology of Religion and Spiritualiy, 5(3), 145-156.

Lucas, R. E. (2007). Adaptation and the Set-Point Model of Subjective Well-Being: Does Happiness Change After Major Life Events? Current Directions In Psychological Science, 16(2), 75-79.

Luhmann, M., Hofmann, W., Eid, M., \& Lucas, R. E. (2012). Subjective Well-Being and Adaptation to Life Events: A Meta-Analysis on Differences Between Cognitive and Affective Well-Being. Journal of Personality and Social Psychology, 102(3), 592-615.

Lykken, D., \& Tellegen, A. (1996). Happiness is a stochastic phenomenon. Psychological Science, 7(3), 186-189.

Martikainen, P., \& Valkonen, T. (1998). Do education and income buffer the effects of death of spouse on mortality? Epidemiology, 9(5), 530-534. 
McDonald, J. H. (2014). Multiple Comparisons. In J. H. McDonald (Ed.), Handbook of Biological Statistics, 3rd edition (pp. 254-60). Baltimore, Maryland: Sparky House Publishing.

Mueller, G. (2006). Conflict Buffers and Marital Satisfaction: On the Effects of Different Forms of Social Support. Journal of Happiness Studies, 7(4), 499-515.

Neugebauer, A., \& Katz, P. P. (2004), Impact of social support on valued activity disability and depressive symptoms in patients with rheumatoid arthritis. Arthritis \& Rheumatism, 51(4), 586-592.

Pocnet, C., Antonietti, JP., Strippoli, MP. F., Glaus, J., Preisig, M. \& Rossier, J. (2016). Individuals' quality of life linked to major life events, perceived social support, and personality traits. Quality of Life Research, 25(11), 28972908.

Ritzer, G. (2007). Blackwell Encyclopedia of Sociology. Blackwell: Blackwell Publishing. https://doi.org/10.1080/13607860802224326

Robb, C., Small, B., \& Haley, W. (2008). Gender differences in coping with functional disability in older married couples: The role of personality and social resources. Aging \& Mental Health, 12(4), 423-433.

Rook, K. S. (1984). The Negative Side of Social Interaction: Impact on Psychological Well-Being, Journal of Personality and Social Psychology, 46(5), 1097-1108.

Sakata, S. (1997). Positive and Negative Effects of Social Support on Depressive Symptoms among the Elderly. Komazawa University, 29, 31-44.

Satija, Y. K., Advani, G. B., \& Nathawat, S. S. (1998). Influence of stressful life events and coping strategies in depression. Indian Journal of Psychiatry, 40(2), 165-171.

Smith, D., Langa, K., Kabeto, M., \& Ubel, P. (2005). Health, wealth, and happiness: Financial resources buffer subjective well-being after the onset of a disability. Psychological Science, 16(9), 663-666.

Strawbridge, W. J., Shema, S. J., Cohen, R. D., Roberts, R. E., \& Kaplan, G. A. (1998). Religiosity buffers effects of some stressors on depression but exacerbates others. Journal of Gerontology: Social Sciences, 53, 118-126.

Stylianos, S. K., \& Vachon, M. L. S. (1993). The role of social support in bereavement. In M. S. Stroebe, R. O.

Hansson, W. Stroebe, \& H. Schut (Eds.), Handbook of bereavement (pp. 397-410). New York: Cambridge University Pre.

Taylor, S. E., \& Stanton, A. L. (2007). Coping resources, coping processes, and mental health. Annual Review of Clinical Psychology, 3, 377-401. http://dx.doi.org/10.1146/annurev.clinpsy.3.022806.091520

Tillmann, R., Voorpostel, M., Kuhn, U., Lebert, F., Ryser, V., Lipps, O., Wernli, B., \& Antal, E. (2016). The Swiss Household Panel Study: Observing Social Change since 1999. Longitudinal and Life Course Studies, 7 (1), $64-78$. https://doi.org/10.14301/1lcs.v7i1.360. 
Van Baarsen, B. (2002). Theories on Coping With Loss: The Impact of Social Support and Self-Esteem on Adjustment to Emotional and Social Loneliness Following a Partner's Death in Later Life. J Gerontol B Psychol Sci Soc Sci, 57(1), 33-42.

Weber, M. (1963). The Sociology of Religion, translated by Ephraim Fishoff. Boston: Beacon Press, 80-137.

Wills, T., \& Isasi, C. (2007). Buffering effect. In Baumeister R. F. \& Vohs K. D. (Eds.). Encyclopedia of Social Psychology. Thousand Oaks: Sage Publications.

Wink, P., Dillon, M., \& Larsen, B. (2005). Religion as Moderator of the Depression-Health Connection. Research on Aging, 27(2), $197-220$.

Yap S., Anusic, I., \& Lucas R. E. (2012). Does personality moderate reaction and adaptation to major life events? Evidence from the British Household Panel Survey. Journal of Research in Personality, 46, 477-488. 
Table 1

Description of the criteria of selection and the number of cases of life events

\begin{tabular}{|c|c|c|}
\hline Event & $\begin{array}{l}\text { Number of } \\
\text { events }\end{array}$ & Criteria of selection \\
\hline $\begin{array}{l}\text { Separation } \\
\text { (end of } \\
\text { cohabitation) }\end{array}$ & $\begin{array}{l}1006 \\
\text { (from } 991 \\
\text { individuals) }\end{array}$ & $\begin{array}{l}\text { Individuals who lived with their partner (at } \mathrm{t}=-1 \text { ) and stopped living } \\
\text { with this partner (at } \mathrm{t}=0 \text { ). Observations after respondents re-partnered } \\
\text { (at } \mathrm{t}=1 \text { and } \mathrm{t}=2 \text { ) were censored. Similarly, observations before } \\
\text { separation (at } \mathrm{t}=-1 \text { and } \mathrm{t}=-2 \text { ) were only considered when the individual } \\
\text { has lived with their partner. Data have been cleaned to exclude cases } \\
\text { where cohabitation ended due to the death of the spouse or a move to an } \\
\text { institution. } 72 \text { individuals experienced multiple separations. }\end{array}$ \\
\hline $\begin{array}{l}\text { Death of a } \\
\text { closely related } \\
\text { person }\end{array}$ & $\begin{array}{l}29,017 \\
\text { (from 12,738 } \\
\text { individuals) }\end{array}$ & $\begin{array}{l}\text { Self-declaration according to the question "have you experienced a } \\
\text { death of a closely related person?" which is asked on an annual basis. } \\
\text { The question refers to the time period since the last interview or } 12 \\
\text { month if there was no interview in the previous wave. } 6830 \text { individuals } \\
\text { experienced multiple death of close persons. }\end{array}$ \\
\hline Unemployment & $\begin{array}{l}1288 \\
\text { (from } 1111 \\
\text { individuals) }\end{array}$ & $\begin{array}{l}\text { Individuals who worked (at } \mathrm{t}=-1 \text { ) and transitioned to unemployed (at } \\
\mathrm{t}=0 \text { ). Observations after the event (at } \mathrm{t}=1 \text { and } \mathrm{t}=2 \text { ) are censored if } \\
\text { individuals are back to employment or retire. } 145 \text { individuals } \\
\text { experienced more than one unemployment spell. }\end{array}$ \\
\hline Disability & $\begin{array}{l}845 \\
\text { (from } 845 \\
\text { individuals) }\end{array}$ & $\begin{array}{l}\text { Individuals who worked (at } \mathrm{t}=-1 \text { ) and stopped working either for } \\
\text { reasons of disability (self-declared) or started receiving a disability } \\
\text { pension (at } \mathrm{t}=0 \text { ). Only the first transition to disability per individual is } \\
\text { considered, because several individuals switch back and forth between } \\
\text { employment and being disabled. After the event (at } \mathrm{t}=-1 \text { and } \mathrm{t}=-2 \text { ), } \\
\text { observations where individuals were working are excluded. }\end{array}$ \\
\hline
\end{tabular}


Table 2

Measurement and coding of resource variables

\begin{tabular}{|c|c|c|}
\hline Resource & Measurement & $\begin{array}{l}\text { Years of data } \\
\text { collection }\end{array}$ \\
\hline \multicolumn{3}{|l|}{ Material resources } \\
\hline Wealth & Relative wealth position of household, net worth & 2012,2016 \\
\hline Income & $\begin{array}{l}\text { Relative income position of household, yearly disposable } \\
\text { household income. The modified OECD equivalence scale has } \\
\text { been used to account for different household sizes. }\end{array}$ & $2000-2016$ \\
\hline \multicolumn{3}{|l|}{ Religious resources } \\
\hline $\begin{array}{l}\text { Religious } \\
\text { attendance }\end{array}$ & $\begin{array}{l}\text { Two groups: 1. attend a religious event less than once a month } \\
\text { (low attendance) } 2 . \text { attend a religious event at least once a } \\
\text { month (high attendance). }\end{array}$ & $1999-2009,2012,2015$ \\
\hline Feeling religious & $\begin{array}{l}\text { Two groups: 1. do not feel religious or feel moderately } \\
\text { religious (low religious) 2. feel quite or very religious (high } \\
\text { religious). }\end{array}$ & 2012,2015 \\
\hline Feeling spiritual & $\begin{array}{l}\text { Two groups } 1 \text {. feel spiritual or feel moderately spiritual (low } \\
\text { spiritual) } 2 \text {. feel quite or very spiritual (high spiritual). }\end{array}$ & 2012,2015 \\
\hline \multicolumn{3}{|l|}{ Social resources } \\
\hline Emotional support & $\begin{array}{l}\text { Two groups: 1. strong emotional support from at least one } \\
\text { person (at least } 9 \text { on a scale from } 0 \text { to 10) 2. no strong support } \\
\text { from at least one person. }\end{array}$ & 1999-2010, 2013, 2016 \\
\hline Number of friends & $\begin{array}{l}\text { Continuous variable, top-coded at } 12 \text {. Since } 2013 \text {, the variable } \\
\text { is collected in categories. } 3-5 \text { friends have been coded as } 4 \\
\text { friends, } 6-10 \text { friends as } 8 \text { friends, and more than } 10 \text { friends as } \\
12 \text { friends. }\end{array}$ & 1999-2010, 2013, 2016 \\
\hline $\begin{array}{l}\text { Frequency of } \\
\text { contact with friends }\end{array}$ & Continuous variable, topcoded at 30 (daily contacts). & 1999-2010, 2013, 2016 \\
\hline \multicolumn{3}{|c|}{ Personality resources: Big Five scale } \\
\hline Conscientious-ness & Self-assessment through three questions (additive scale) & 2015 \\
\hline Openness & Self-assessment through three questions (additive scale) & 2015 \\
\hline Agreeableness & Self-assessment through three questions(additive scale) & 2015 \\
\hline
\end{tabular}




\begin{tabular}{|l|l|l|}
\hline Extraversion & Self-assessment through three questions (additive scale) & 2015 \\
\hline Neuroticism & Self-assessment through three questions (additive scale) & 2015 \\
\hline
\end{tabular}


Table 3

Summary of buffering effects of 4 types of resources (material, religion, social and personality) on 4 life events (separation, death of a closely related person, unemployment and disability)

\begin{tabular}{|c|c|c|c|c|c|c|c|c|}
\hline & \multicolumn{2}{|c|}{$\begin{array}{l}\text { Separation } \\
(n=618-982)\end{array}$} & \multicolumn{2}{|c|}{$\begin{array}{l}\text { Death closely related } \\
\text { person } \quad(\mathrm{n}=5387- \\
10651)\end{array}$} & \multicolumn{2}{|c|}{$\begin{array}{l}\text { Unemployment } \\
(\mathrm{n}=637-1118)\end{array}$} & \multicolumn{2}{|c|}{$\begin{array}{l}\text { Disability } \\
(n=422-824)\end{array}$} \\
\hline years since event & 1 & 2 & 1 & 2 & 1 & 2 & 1 & 2 \\
\hline \multicolumn{9}{|l|}{ Material resources } \\
\hline Wealth & -0.212 & $-0.557^{*}$ & 0.015 & 0.058 & 0.054 & -0.362 & -0.009 & -0.156 \\
\hline Income & -0.271 & 0.235 & $-0.133^{*}$ & -0.134 & -0.326 & 0.300 & -0.423 & -0.526 \\
\hline \multicolumn{9}{|l|}{ Religious resources } \\
\hline Religious attendance & $-0.515^{*}$ & -0.300 & -0.002 & -0.041 & 0.203 & $0.843 * *$ & $0.530 *$ & 0.360 \\
\hline Feel religious & -0.203 & 0.086 & $0.106 *$ & 0.041 & 0.194 & 0.129 & 0.424 & $0.608 * *$ \\
\hline Feel spiritual & 0.078 & 0.155 & $0.121 * *$ & 0.077 & 0.251 & $0.695 *$ & 0.387 & $0.571 *$ \\
\hline \multicolumn{9}{|l|}{ Social resources } \\
\hline Emotional support & -0.034 & -0.138 & $-0.139 * *$ & $-0.097^{*}$ & 0.248 & $0.603 * *$ & -0.156 & 0.049 \\
\hline Number friends & -0.284 & -0.284 & $-0.162 * *$ & $-0.188 * *$ & $-0.619 *$ & 0.007 & -0.186 & $-0.736^{*}$ \\
\hline Frequency contact friends & 0.265 & -0.253 & $-0.186^{* *}$ & $-0.273 * *$ & 0.051 & -0.602 & 0.449 & 0.730 \\
\hline \multicolumn{9}{|l|}{ Personality resources } \\
\hline Conscientiousness & -0.283 & -0.347 & 0.002 & 0.086 & -1.001 & 0.119 & 0.121 & -0.216 \\
\hline Openness & 0.161 & 0.714 & 0.180 & 0.185 & 0.511 & 0.099 & -0.398 & -0.544 \\
\hline Agreeableness & 0.241 & -1.147 & 0.111 & 0.176 & -0.914 & -0.495 & 0.852 & $1.516 *$ \\
\hline Extraversion & 0.249 & 0.602 & 0.149 & 0.065 & -0.807 & 0.096 & -0.148 & 0.252 \\
\hline Neuroticism & -0.498 & -0.330 & -0.174 & $-0.284 *$ & -0.687 & $-2.087 * *$ & -0.693 & -0.019 \\
\hline
\end{tabular}

Note: Interaction coefficients between resources and years (1 and 2) after the event of 52 Fixed effects regression models (13 resources, 4 events). See the appendix for complete regression tables. ** $\mathrm{p}<0.01, * \mathrm{p}<0.05$ Positive effects are highlighted. Source: Swiss Household Panel 1999-2016. 


\section{Appendix for Comparison of buffering effects for negative life events}

\section{Questions and response categories, definition of income}

Income: Sum of total household income from labour earnings, private transfers, public transfers, social security pensions, imputed rental value and asset income minus total household taxes and health insurance premiums. Household member's needs are equivalized according to the modified OECD scale: household head: 1, household members 14 years or older: 0.5 , household members 13 years or younger: 0.3 .

Wealth: Total household wealth. Sum of value of owner occupied housing and other wealth.

\section{Religious attendance:}

Question: "How frequently do you take part in religious services? “

Open response categories.

\section{Feel religious:}

Question: "All in all, how religious would you consider yourself to be?"

Response categories: Not at all, not very much, moderately, quite, or very religious?

\section{Feel spiritual:}

Question: "Putting aside whether or not you would describe yourself as a religious person, how spiritual would you say you are? "

Response categories: Not at all, not very much, moderately, quite, or very spiritual?

\section{Emotional support}

Question asked to individuals who say to have friends, neighbours with whom respondents are on good terms and enjoy a close relationship, colleagues and acquaintances, or family members. There are separate questions for each type of network members.

Question: "And to what extent can these friends (neighbours, colleagues and acquaintances, family members) be available in case of need and show understanding, by talking with you for example, if 0 means "not at all" and 10 "a great deal"?"

In 2013 and 2016, questions the question is asked for different family members separately (mother, father, siblings, other important family ties), rather than for family members in general (1999-2010).

\section{Number of friends:}

Question: "How many good and close friends do you have?"

Open response categories 1999-2010. Response categories (since 2013): 0 friends, 1 friend, 2 friends, 2-5 friends, 610 friends, more than 10 friends.

\section{Frequency of contact with friends:}

Question: "How frequent are your contacts with these friends?"

\section{Big five inventory 15:}

Question: "We are now going to make some statements. Please tell me how well do the following statements describe your personality ? 0 means "not at all" and 10 "completely". I am someone who..."

...does a thorough job (conscientiousness)

...is talkative (extraversion) 
....is sometimes rude to others (agreeableness)

...is original, comes up with new ideas (openness)

...worries a lot (neuroticism)

...has a forgiving nature (agreeableness)

...tends to be lazy (conscientiousness)

....is outgoing, sociable (extraversion)

...values artistic experiences (openness)

....gets nervous easily (neuroticism)

...does things efficiently (conscientiousness)

....is reserved (extraversion)

...is considerate and kind to almost everyone (agreeableness)

...has an active imagination (openness)

...remains calm in tense situations (neuroticism) 
Table A1: descriptive statistics

\begin{tabular}{lcccc}
\hline Variable & Obs & Mean & Std.Dev. & Min \\
\hline Life satisfaction & 130,069 & 8.061 & 1.419 & 0 \\
Wealth (relative position) & 163,354 & 0.500 & 0.295 & 0 \\
Disposable household income (relative position) & 97,173 & 0.437 & 0.292 & 0 \\
Religious attendance (at least monthly) & 148,298 & 0.229 & 0.420 & 0 \\
Religious feelings (quite or very religious) & 126,117 & 0.174 & 0.379 & 0 \\
Spiritual feelings (quite or very spiritual) & 125,598 & 0.192 & 0.394 & 0 \\
Emotional support (at least one person with 9 or 10 ) & 97,820 & 0.680 & 0.467 & 0 \\
Number of friends (range before standardization: 0-12) & 170,999 & 0.414 & 0.271 & 0 \\
Frequency of contact with friends (range before standardization: 0-30 per month) & 170,853 & 0.287 & 0.303 & 0 \\
Conscientiousness (additive scale, range before standardization: 0-30) & 95,275 & 0.668 & 0.170 & 0 \\
Openness (additive scale, range before standardization: 0-30) & 94,910 & 0.649 & 0.155 & 0 \\
Agreeableness (additive scale, range before standardization: 0-30) & 95,295 & 0.689 & 0.140 & 0 \\
Extraversion (additive scale, range before standardization: 0-30) & 95,283 & 0.515 & 0.137 & 0 \\
Neuroticism (additive scale, range before standardization: 0-30) & 95,323 & 0.432 & 0.163 & 0 \\
\hline
\end{tabular}

Source: SHP 1999-2016 
Table A2: Buffering effect for separation: material resources, religious resources, social resources

\begin{tabular}{|c|c|c|c|c|c|c|c|c|}
\hline & Wealth & Income & $\begin{array}{c}\text { Religious } \\
\text { participation }\end{array}$ & $\begin{array}{l}\text { Feel } \\
\text { religious }\end{array}$ & $\begin{array}{c}\text { Feel } \\
\text { spiritual }\end{array}$ & $\begin{array}{c}\text { Emotional } \\
\text { support }\end{array}$ & $\begin{array}{l}\text { Number } \\
\text { friends }\end{array}$ & $\begin{array}{c}\text { Frequency } \\
\text { contact friends }\end{array}$ \\
\hline \multicolumn{9}{|l|}{ Time to event (Ref: two years before) } \\
\hline \multirow[t]{2}{*}{ One year before } & -0.126 & -0.380 & $-0.280 * *$ & $-0.263 * *$ & $-0.227 * *$ & $-0.268 *$ & -0.118 & $-0.355^{* *}$ \\
\hline & $(0.117)$ & $(0.223)$ & $(0.070)$ & $(0.075)$ & $(0.078)$ & $(0.120)$ & $(0.121)$ & $(0.087)$ \\
\hline \multirow[t]{2}{*}{ Shortly after } & $-0.527 * *$ & $-0.618 * *$ & $-0.570 * *$ & $-0.614 * *$ & $-0.656 * *$ & $-0.504 * *$ & $-0.530 * *$ & $-0.745^{* *}$ \\
\hline & $(0.116)$ & $(0.185)$ & $(0.070)$ & $(0.074)$ & $(0.078)$ & $(0.119)$ & $(0.121)$ & $(0.087)$ \\
\hline \multirow[t]{2}{*}{ One year after } & -0.236 & -0.202 & $-0.293 * *$ & $-0.296 * *$ & $-0.345 * *$ & $-0.347 * *$ & -0.257 & $-0.427 * *$ \\
\hline & $(0.127)$ & $(0.196)$ & $(0.077)$ & $(0.083)$ & $(0.086)$ & $(0.129)$ & $(0.133)$ & $(0.096)$ \\
\hline \multirow[t]{2}{*}{ Two years after } & 0.174 & -0.019 & -0.073 & -0.061 & -0.085 & -0.025 & -0.085 & -0.052 \\
\hline & $(0.138)$ & $(0.207)$ & $(0.085)$ & $(0.090)$ & $(0.095)$ & $(0.141)$ & $(0.147)$ & $(0.106)$ \\
\hline \multirow[t]{2}{*}{ One year before $*$ buffer } & -0.306 & 0.445 & -0.135 & 0.068 & -0.139 & -0.048 & -0.473 & 0.243 \\
\hline & $(0.219)$ & $(0.390)$ & $(0.211)$ & $(0.205)$ & $(0.173)$ & $(0.144)$ & $(0.270)$ & $(0.248)$ \\
\hline \multirow[t]{2}{*}{ Shortly after * buffer } & -0.199 & 0.254 & $-0.753 * *$ & -0.059 & 0.162 & -0.248 & -0.328 & 0.375 \\
\hline & $(0.218)$ & $(0.379)$ & $(0.209)$ & $(0.204)$ & $(0.172)$ & $(0.143)$ & $(0.269)$ & $(0.248)$ \\
\hline \multirow[t]{2}{*}{ One year after $*$ buffer } & -0.212 & -0.271 & $-0.515^{*}$ & -0.203 & 0.078 & -0.034 & -0.284 & 0.265 \\
\hline & $(0.238)$ & $(0.412)$ & $(0.226)$ & $(0.216)$ & $(0.184)$ & $(0.156)$ & $(0.295)$ & $(0.272)$ \\
\hline \multirow[t]{2}{*}{ Two year after * buffer } & $-0.557 *$ & 0.235 & -0.300 & 0.086 & 0.155 & -0.138 & -0.075 & -0.253 \\
\hline & $(0.256)$ & $(0.441)$ & $(0.248)$ & $(0.236)$ & $(0.200)$ & $(0.171)$ & $(0.322)$ & $(0.311)$ \\
\hline \multirow[t]{2}{*}{ Buffer variable (Ref: low resources) } & & 0.140 & 0.397 & & & 0.460 & -0.209 & -0.690 \\
\hline & & $(0.315)$ & $(0.443)$ & & & $(0.425)$ & $(0.444)$ & $(0.484)$ \\
\hline \multirow[t]{2}{*}{ Constant } & $7.662 * *$ & $7.543 * *$ & $7.625 * *$ & $7.663 * *$ & $7.664 * *$ & $7.351 * *$ & $7.778 * *$ & $7.860 * *$ \\
\hline & $(0.052)$ & $(0.172)$ & $(0.071)$ & $(0.053)$ & $(0.053)$ & $(0.295)$ & $(0.179)$ & $(0.130)$ \\
\hline Observations & 3,336 & 2,446 & 3,838 & 3,274 & 3,271 & 3,773 & 3,967 & 3,964 \\
\hline Number of individuals & 781 & 919 & 953 & 766 & 765 & 919 & 982 & 981 \\
\hline R-squared & 0.039 & 0.045 & 0.045 & 0.039 & 0.040 & 0.043 & 0.041 & 0.042 \\
\hline
\end{tabular}

Note: Standard errors in parentheses; $* * \mathrm{p}<0.01,{ }^{*} \mathrm{p}<0.05$; Source: SHP 2000-2016. 
Table A3: Buffering effect for separation: personality resources

\begin{tabular}{|c|c|c|c|c|c|}
\hline & $\begin{array}{l}\text { Conscien- } \\
\text { tiousness }\end{array}$ & Openness & Agreeableness & Extraversion & Neuroticism \\
\hline \multicolumn{6}{|c|}{ Time to event (Ref: two years before) } \\
\hline \multirow[t]{2}{*}{ One year before } & -0.206 & -0.436 & -0.099 & -0.293 & -0.183 \\
\hline & $(0.312)$ & $(0.326)$ & $(0.394)$ & $(0.294)$ & $(0.213)$ \\
\hline \multirow[t]{2}{*}{ Shortly after } & -0.439 & $-0.847 * *$ & -0.483 & $-1.134 * *$ & -0.267 \\
\hline & $(0.311)$ & $(0.327)$ & $(0.393)$ & $(0.293)$ & $(0.211)$ \\
\hline \multirow[t]{2}{*}{ One year after } & -0.094 & -0.393 & -0.456 & -0.418 & -0.078 \\
\hline & $(0.329)$ & $(0.347)$ & $(0.427)$ & $(0.317)$ & $(0.230)$ \\
\hline \multirow[t]{2}{*}{ Two years after } & 0.199 & -0.513 & 0.772 & -0.350 & 0.103 \\
\hline & $(0.357)$ & $(0.378)$ & $(0.460)$ & $(0.340)$ & $(0.247)$ \\
\hline \multirow[t]{2}{*}{ One year before $*$ buffer } & -0.073 & 0.274 & -0.222 & 0.077 & -0.171 \\
\hline & $(0.444)$ & $(0.475)$ & $(0.556)$ & $(0.539)$ & $(0.473)$ \\
\hline \multirow[t]{2}{*}{ Shortly after $*$ buffer } & -0.328 & 0.278 & -0.260 & 0.891 & $-0.949 *$ \\
\hline & $(0.441)$ & $(0.475)$ & $(0.554)$ & $(0.537)$ & $(0.470)$ \\
\hline \multirow[t]{2}{*}{ One year after $*$ buffer } & -0.283 & 0.161 & 0.241 & 0.249 & -0.498 \\
\hline & $(0.471)$ & $(0.505)$ & $(0.600)$ & $(0.582)$ & $(0.508)$ \\
\hline \multirow[t]{2}{*}{ Two year after * buffer } & -0.347 & 0.714 & -1.147 & 0.602 & -0.330 \\
\hline & $(0.510)$ & $(0.546)$ & $(0.643)$ & $(0.628)$ & $(0.550)$ \\
\hline \multirow[t]{2}{*}{ Constant } & $7.615 * *$ & $7.619 * *$ & $7.615 * *$ & $7.614 * *$ & $7.615 * *$ \\
\hline & $(0.058)$ & $(0.058)$ & $(0.058)$ & $(0.058)$ & $(0.058)$ \\
\hline Observations & 2,736 & 2,731 & 2,732 & 2,732 & 2,732 \\
\hline Number of individuals & 619 & 617 & 618 & 618 & 618 \\
\hline R-squared & 0.043 & 0.043 & 0.045 & 0.044 & 0.045 \\
\hline
\end{tabular}

Note: Standard errors in parentheses; $* * \mathrm{p}<0.01,{ }^{*} \mathrm{p}<0.05$; Source: SHP 2000-2016. 
Table A4: Buffering effect for death of a close person: material resources, religious resources, social resources

\begin{tabular}{|c|c|c|c|c|c|c|c|c|}
\hline & Wealth & Income & $\begin{array}{c}\text { Religious } \\
\text { participation }\end{array}$ & $\begin{array}{c}\text { Feel } \\
\text { religious }\end{array}$ & $\begin{array}{c}\text { Feel } \\
\text { spiritual }\end{array}$ & $\begin{array}{l}\text { Emotional } \\
\text { support }\end{array}$ & $\begin{array}{l}\text { Number } \\
\text { friends }\end{array}$ & $\begin{array}{c}\text { Frequency } \\
\text { contact } \\
\text { friends }\end{array}$ \\
\hline \multicolumn{9}{|l|}{ Time to event (Ref: two years before) } \\
\hline One year before & $(0.033)$ & $(0.033)$ & $(0.018)$ & $(0.018)$ & $(0.018)$ & $(0.028)$ & $(0.029)$ & $(0.021)$ \\
\hline \multirow[t]{2}{*}{ Shortly after } & $-0.083 * *$ & -0.021 & $-0.075^{* *}$ & $-0.092 * *$ & $-0.090 * *$ & -0.024 & -0.002 & $-0.051 * *$ \\
\hline & $(0.030)$ & $(0.031)$ & $(0.017)$ & $(0.017)$ & $(0.017)$ & $(0.025)$ & $(0.026)$ & (0.019) \\
\hline \multirow[t]{2}{*}{ One year after } & $-0.110 * *$ & -0.042 & $-0.101 * *$ & $-0.125^{* *}$ & $-0.129 * *$ & -0.010 & -0.050 & $-0.073 * *$ \\
\hline & $(0.034)$ & $(0.036)$ & (0.019) & $(0.019)$ & $(0.019)$ & $(0.029)$ & $(0.030)$ & $(0.022)$ \\
\hline \multirow[t]{2}{*}{ Two years after } & $-0.162 * *$ & -0.051 & $-0.124 * *$ & $-0.140 * *$ & $-0.146 * *$ & $-0.073^{*}$ & $-0.077^{*}$ & $-0.089 * *$ \\
\hline & $(0.038)$ & $(0.041)$ & $(0.021)$ & $(0.021)$ & $(0.021)$ & $(0.032)$ & $(0.033)$ & $(0.024)$ \\
\hline \multirow[t]{2}{*}{ One year before $*$ buffer } & 0.064 & -0.060 & -0.020 & 0.069 & -0.010 & -0.060 & $-0.173 * *$ & -0.087 \\
\hline & $(0.054)$ & $(0.061)$ & $(0.038)$ & $(0.042)$ & $(0.041)$ & $(0.034)$ & $(0.058)$ & $(0.058)$ \\
\hline Shortly after $*$ buffer & 0.010 & $-0.150 * *$ & -0.003 & 0.069 & 0.060 & $-0.080^{* *}$ & $-0.201^{* *}$ & $-0.150 * *$ \\
\hline \multirow[t]{2}{*}{ One year after $*$ buffer } & 0.015 & $-0.133 *$ & -0.002 & $0.106 *$ & $0.121 * *$ & $-0.139 * *$ & $-0.162 * *$ & $-0.186 * *$ \\
\hline & $(0.057)$ & $(0.065)$ & $(0.039)$ & $(0.044)$ & $(0.042)$ & $(0.035)$ & $(0.060)$ & $(0.060)$ \\
\hline \multirow[t]{2}{*}{ Two year after * buffer } & 0.058 & -0.134 & -0.041 & 0.041 & 0.077 & $-0.097 *$ & $-0.188 * *$ & $-0.273 * *$ \\
\hline & $(0.063)$ & $(0.074)$ & $(0.044)$ & $(0.049)$ & $(0.047)$ & $(0.039)$ & $(0.066)$ & $(0.067)$ \\
\hline \multirow[t]{2}{*}{ Buffer variable (Ref: low resources) } & & 0.071 & $0.098^{*}$ & & & $0.165 * *$ & $0.279 * *$ & $0.205^{* *}$ \\
\hline & & $(0.089)$ & $(0.047)$ & & & $(0.038)$ & $(0.064)$ & $(0.068)$ \\
\hline \multirow[t]{2}{*}{ Constant } & $8.118^{* *}$ & $8.055^{* *}$ & $8.055^{* *}$ & $8.122 * *$ & $8.123^{* *}$ & $7.970 * *$ & $7.995^{* *}$ & $8.062 * *$ \\
\hline & $(0.013)$ & $(0.044)$ & $(0.017)$ & $(0.013)$ & $(0.013)$ & $(0.028)$ & $(0.029)$ & $(0.020)$ \\
\hline Observations & 49,834 & 40,410 & 53,451 & 48,473 & 48,339 & 52,378 & 58,334 & 58,311 \\
\hline Number of individuals & 8,002 & 7,537 & 9,099 & 7,658 & 7,630 & 8,613 & 10,431 & 10,421 \\
\hline R-squared & 0.002 & 0.002 & 0.002 & 0.002 & 0.002 & 0.002 & 0.003 & 0.003 \\
\hline
\end{tabular}

Note: Standard errors in parentheses; $* * \mathrm{p}<0.01,{ }^{*} \mathrm{p}<0.05$; Source: SHP 1999-2016. 
Table A5: Buffering effect for death of a close person: personality resources

\begin{tabular}{|c|c|c|c|c|c|}
\hline & Conscientiousness & Openness & Agreeableness & Extraversion & Neuroticism \\
\hline \multicolumn{6}{|c|}{ Time to event (Ref: two years before) } \\
\hline \multirow[t]{2}{*}{ One year before } & -0.112 & -0.039 & -0.136 & -0.090 & 0.005 \\
\hline & $(0.076)$ & $(0.079)$ & $(0.091)$ & $(0.069)$ & $(0.051)$ \\
\hline \multirow[t]{2}{*}{ Shortly after } & -0.117 & -0.111 & $-0.172 *$ & -0.064 & -0.015 \\
\hline & $(0.069)$ & $(0.071)$ & $(0.082)$ & $(0.063)$ & $(0.046)$ \\
\hline \multirow[t]{2}{*}{ One year after } & -0.083 & $-0.197^{*}$ & -0.158 & $-0.157^{*}$ & -0.005 \\
\hline & $(0.078)$ & $(0.080)$ & $(0.094)$ & $(0.071)$ & $(0.053)$ \\
\hline \multirow[t]{2}{*}{ Two years after } & -0.163 & $-0.223^{*}$ & $-0.226^{*}$ & -0.139 & 0.019 \\
\hline & $(0.086)$ & $(0.088)$ & $(0.102)$ & $(0.078)$ & $(0.058)$ \\
\hline \multirow[t]{2}{*}{ One year before $*$ buffer } & 0.113 & 0.007 & 0.146 & 0.109 & -0.092 \\
\hline & (0.109) & $(0.118)$ & $(0.129)$ & $(0.132)$ & $(0.111)$ \\
\hline \multirow[t]{2}{*}{ Shortly after $*$ buffer } & 0.095 & 0.091 & 0.174 & 0.025 & -0.086 \\
\hline & $(0.098)$ & $(0.106)$ & $(0.116)$ & $(0.118)$ & $(0.100)$ \\
\hline \multirow[t]{2}{*}{ One year after $*$ buffer } & 0.002 & 0.180 & 0.111 & 0.149 & -0.174 \\
\hline & $(0.112)$ & $(0.120)$ & $(0.133)$ & $(0.135)$ & $(0.114)$ \\
\hline \multirow[t]{2}{*}{ Two year after $*$ buffer } & 0.086 & 0.185 & 0.176 & 0.065 & $-0.284^{*}$ \\
\hline & $(0.124)$ & $(0.132)$ & $(0.145)$ & $(0.147)$ & $(0.125)$ \\
\hline \multirow[t]{2}{*}{ Constant } & $8.093^{* *}$ & $8.096 * *$ & $8.091 * *$ & $8.092 * *$ & $8.094 * *$ \\
\hline & $(0.014)$ & $(0.014)$ & $(0.014)$ & $(0.014)$ & $(0.014)$ \\
\hline Observations & 39,332 & 39,185 & 39,347 & 39,346 & 39,374 \\
\hline Number of individuals & 5,408 & 5,387 & 5,409 & 5,409 & 5,411 \\
\hline R-squared & 0.001 & 0.001 & 0.001 & 0.001 & 0.001 \\
\hline
\end{tabular}


Table A6: Buffering effect for unemployment: material resources, religious resources, social resources

\begin{tabular}{|c|c|c|c|c|c|c|c|c|}
\hline & Wealth & Income & $\begin{array}{c}\text { Religious } \\
\text { participation }\end{array}$ & $\begin{array}{l}\text { Feel } \\
\text { religious }\end{array}$ & $\begin{array}{c}\text { Feel } \\
\text { spiritual }\end{array}$ & $\begin{array}{l}\text { Emotional } \\
\text { support }\end{array}$ & $\begin{array}{l}\text { Number } \\
\text { friends }\end{array}$ & $\begin{array}{l}\quad(8) \\
\text { Frequency } \\
\text { contact } \\
\text { friends }\end{array}$ \\
\hline \multicolumn{9}{|l|}{ Time to event (Ref: two years before) } \\
\hline \multirow[t]{2}{*}{ One year before } & -0.133 & -0.222 & $-0.187 * *$ & $-0.202 * *$ & $-0.216 * *$ & $-0.214^{*}$ & $-0.256^{*}$ & $-0.176^{*}$ \\
\hline & $(0.104)$ & $(0.123)$ & $(0.066)$ & $(0.067)$ & $(0.069)$ & $(0.105)$ & $(0.110)$ & $(0.087)$ \\
\hline \multirow[t]{2}{*}{ Shortly after } & $-0.446 * *$ & $-0.578 * *$ & $-0.527 * *$ & $-0.538 * *$ & $-0.535 * *$ & $-0.459 * *$ & $-0.536 * *$ & $-0.550 * *$ \\
\hline & $(0.103)$ & $(0.121)$ & $(0.066)$ & $(0.067)$ & $(0.069)$ & $(0.104)$ & $(0.108)$ & $(0.086)$ \\
\hline \multirow[t]{2}{*}{ One year after } & $-0.437 * *$ & -0.330 & $-0.501 * *$ & $-0.456 * *$ & $-0.486 * *$ & $-0.641 * *$ & -0.238 & $-0.507^{* *}$ \\
\hline & $(0.152)$ & $(0.177)$ & $(0.097)$ & (0.099) & $(0.103)$ & $(0.154)$ & $(0.153)$ & $(0.124)$ \\
\hline \multirow[t]{2}{*}{ Two years after } & -0.266 & $-0.590 * *$ & $-0.615^{* *}$ & $-0.456 * *$ & $-0.589 * *$ & $-0.918 * *$ & $-0.516 * *$ & -0.295 \\
\hline & $(0.189)$ & $(0.221)$ & $(0.121)$ & $(0.121)$ & $(0.126)$ & $(0.190)$ & $(0.198)$ & $(0.160)$ \\
\hline \multirow[t]{2}{*}{ One year before $*$ buffer } & -0.122 & 0.081 & -0.014 & 0.075 & 0.101 & 0.048 & 0.126 & -0.061 \\
\hline & $(0.207)$ & $(0.228)$ & $(0.162)$ & $(0.179)$ & $(0.157)$ & $(0.128)$ & $(0.212)$ & $(0.172)$ \\
\hline \multirow[t]{2}{*}{ Shortly after $*$ buffer } & -0.119 & 0.095 & 0.199 & 0.200 & 0.150 & -0.074 & 0.068 & 0.119 \\
\hline & $(0.205)$ & $(0.225)$ & $(0.160)$ & $(0.177)$ & $(0.154)$ & $(0.126)$ & (0.209) & $(0.171)$ \\
\hline \multirow[t]{2}{*}{ One year after * buffer } & 0.054 & -0.326 & 0.203 & 0.194 & 0.251 & 0.248 & $-0.619 *$ & 0.051 \\
\hline & $(0.303)$ & $(0.342)$ & $(0.239)$ & $(0.263)$ & $(0.223)$ & $(0.187)$ & $(0.303)$ & $(0.255)$ \\
\hline \multirow[t]{2}{*}{ Two year after * buffer } & -0.362 & 0.300 & $0.843 * *$ & 0.129 & $0.695^{*}$ & $0.603 * *$ & 0.007 & -0.602 \\
\hline & $(0.368)$ & $(0.423)$ & $(0.301)$ & $(0.333)$ & $(0.283)$ & $(0.232)$ & $(0.374)$ & $(0.325)$ \\
\hline \multirow[t]{2}{*}{ Buffer variable (Ref: low resources) } & & -0.049 & -0.188 & & & -0.060 & -0.397 & -0.036 \\
\hline & & $(0.625)$ & $(0.311)$ & & & $(0.237)$ & $(0.378)$ & $(0.302)$ \\
\hline \multirow[t]{2}{*}{ Constant } & $7.744^{* *}$ & $7.719 * *$ & $7.701 * *$ & $7.751 * *$ & $7.756 * *$ & $7.722 * *$ & $7.885^{* *}$ & $7.723 * *$ \\
\hline & $(0.047)$ & $(0.287)$ & $(0.070)$ & $(0.047)$ & $(0.047)$ & $(0.166)$ & $(0.172)$ & $(0.120)$ \\
\hline Observations & 3,222 & 2,998 & 3,642 & 3,164 & 3,145 & 3,586 & 3,876 & 3,876 \\
\hline Number of individuals & 884 & 847 & 1,036 & 868 & 863 & 996 & 1,100 & 1,100 \\
\hline R-squared & 0.032 & 0.039 & 0.035 & 0.034 & 0.036 & 0.038 & 0.036 & 0.035 \\
\hline
\end{tabular}


Table A7: Buffering effect for unemployment: psychological resources

Conscientiousness Openness Agreeableness Extraversion Neuroticism

\begin{tabular}{|c|c|c|c|c|c|}
\hline \multirow[t]{2}{*}{ One year before } & -0.036 & -0.035 & 0.166 & -0.412 & -0.345 \\
\hline & $(0.265)$ & $(0.321)$ & $(0.351)$ & $(0.271)$ & $(0.208)$ \\
\hline \multirow[t]{2}{*}{ Shortly after } & -0.438 & -0.291 & -0.168 & $-0.662 *$ & $-0.503 *$ \\
\hline & $(0.261)$ & $(0.315)$ & $(0.346)$ & $(0.266)$ & $(0.205)$ \\
\hline \multirow[t]{2}{*}{ One year after } & 0.214 & -0.784 & 0.173 & -0.042 & -0.115 \\
\hline & $(0.380)$ & $(0.460)$ & $(0.462)$ & $(0.383)$ & (0.299) \\
\hline \multirow[t]{2}{*}{ Two years after } & -0.471 & -0.460 & -0.059 & -0.445 & 0.564 \\
\hline & $(0.460)$ & $(0.573)$ & $(0.540)$ & $(0.477)$ & $(0.345)$ \\
\hline \multirow[t]{2}{*}{ One year before $*$ buffer } & -0.249 & -0.238 & -0.536 & 0.405 & 0.333 \\
\hline & $(0.394)$ & $(0.460)$ & $(0.506)$ & $(0.496)$ & $(0.427)$ \\
\hline \multirow[t]{2}{*}{ Shortly after * buffer } & -0.180 & -0.393 & -0.572 & 0.203 & -0.113 \\
\hline & $(0.389)$ & $(0.453)$ & $(0.498)$ & $(0.487)$ & $(0.419)$ \\
\hline \multirow[t]{2}{*}{ One year after * buffer } & -1.001 & 0.511 & -0.914 & -0.807 & -0.687 \\
\hline & $(0.560)$ & $(0.666)$ & $(0.674)$ & $(0.727)$ & $(0.591)$ \\
\hline \multirow[t]{2}{*}{ Two year after * buffer } & 0.119 & 0.099 & -0.495 & 0.096 & $-2.087 * *$ \\
\hline & $(0.678)$ & $(0.823)$ & $(0.793)$ & $(0.905)$ & $(0.704)$ \\
\hline \multirow[t]{2}{*}{ Constant } & $7.715^{* *}$ & $7.717^{* *}$ & $7.715^{* *}$ & $7.717 * *$ & $7.715^{* *}$ \\
\hline & $(0.054)$ & $(0.054)$ & $(0.054)$ & $(0.054)$ & $(0.054)$ \\
\hline Observations & 2,452 & 2,445 & 2,452 & 2,447 & 2,443 \\
\hline Number of individuals & 639 & 637 & 639 & 638 & 637 \\
\hline R-squared & 0.039 & 0.039 & 0.038 & 0.039 & 0.044 \\
\hline
\end{tabular}


Table A8: Buffering effect for disability: material resources, religious resources, social resources

\begin{tabular}{|c|c|c|c|c|c|c|c|c|}
\hline & Wealth & Income & $\begin{array}{c}\text { Religious } \\
\text { participation }\end{array}$ & $\begin{array}{l}\text { Feel } \\
\text { religious }\end{array}$ & $\begin{array}{c}\text { Feel } \\
\text { spiritual }\end{array}$ & $\begin{array}{l}\text { Emotional } \\
\text { support }\end{array}$ & $\begin{array}{l}\text { Number } \\
\text { friends }\end{array}$ & $\begin{array}{c}\text { Frequency } \\
\text { contact } \\
\text { friends }\end{array}$ \\
\hline \multicolumn{9}{|c|}{ Time to event (Ref: two years before) } \\
\hline \multirow[t]{2}{*}{ One year before } & -0.197 & 0.055 & -0.059 & -0.118 & -0.133 & 0.040 & -0.064 & -0.097 \\
\hline & $(0.157)$ & $(0.137)$ & $(0.102)$ & $(0.106)$ & $(0.104)$ & $(0.128)$ & $(0.139)$ & $(0.107)$ \\
\hline \multirow[t]{2}{*}{ Shortly after } & $-0.344^{*}$ & $-0.335^{*}$ & $-0.565 * *$ & $-0.500 * *$ & $-0.459 * *$ & $-0.355^{* *}$ & -0.246 & $-0.480 * *$ \\
\hline & $(0.152)$ & $(0.135)$ & (0.099) & $(0.104)$ & $(0.102)$ & $(0.126)$ & $(0.135)$ & $(0.104)$ \\
\hline \multirow[t]{2}{*}{ One year after } & $-0.371^{*}$ & -0.189 & $-0.515^{* *}$ & $-0.485^{* *}$ & $-0.457 * *$ & -0.272 & $-0.323^{*}$ & $-0.478 * *$ \\
\hline & $(0.168)$ & $(0.147)$ & $(0.111)$ & $(0.114)$ & $(0.112)$ & $(0.139)$ & $(0.148)$ & $(0.116)$ \\
\hline \multirow[t]{2}{*}{ Two years after } & -0.052 & 0.019 & $-0.283^{*}$ & $-0.312^{*}$ & $-0.287^{*}$ & -0.199 & 0.075 & $-0.326 * *$ \\
\hline & $(0.181)$ & $(0.157)$ & $(0.118)$ & $(0.121)$ & (0.119) & $(0.145)$ & $(0.160)$ & $(0.124)$ \\
\hline \multirow[t]{2}{*}{ One year before $*$ buffer } & 0.248 & -0.228 & -0.010 & 0.239 & 0.322 & -0.190 & -0.011 & 0.139 \\
\hline & $(0.259)$ & (0.319) & (0.191) & $(0.203)$ & $(0.210)$ & $(0.173)$ & $(0.291)$ & $(0.348)$ \\
\hline \multirow[t]{2}{*}{ Shortly after * buffer } & -0.116 & -0.218 & 0.345 & 0.282 & 0.127 & -0.185 & $-0.595^{*}$ & 0.058 \\
\hline & $(0.252)$ & $(0.313)$ & $(0.187)$ & $(0.200)$ & $(0.207)$ & $(0.169)$ & $(0.283)$ & $(0.342)$ \\
\hline \multirow[t]{2}{*}{ One year after * buffer } & -0.009 & -0.423 & $0.530^{*}$ & 0.424 & 0.387 & -0.156 & -0.186 & 0.449 \\
\hline & $(0.275)$ & $(0.353)$ & $(0.207)$ & $(0.220)$ & $(0.230)$ & $(0.189)$ & $(0.310)$ & $(0.393)$ \\
\hline \multirow[t]{2}{*}{ Two year after * buffer } & -0.156 & -0.526 & 0.360 & $0.608 * *$ & $0.571^{*}$ & 0.049 & $-0.736 *$ & 0.730 \\
\hline & $(0.292)$ & $(0.375)$ & $(0.221)$ & $(0.229)$ & $(0.239)$ & $(0.201)$ & $(0.340)$ & $(0.418)$ \\
\hline \multirow[t]{2}{*}{ Constant } & $7.452 * *$ & $7.370 * *$ & $7.338^{* *}$ & $7.468 * *$ & $7.472 * *$ & $7.367^{* *}$ & $7.378 * *$ & $7.381 * *$ \\
\hline & $(0.066)$ & $(0.066)$ & $(0.064)$ & $(0.067)$ & $(0.067)$ & $(0.063)$ & $(0.063)$ & $(0.063)$ \\
\hline Observations & 2,382 & 2,555 & 2,815 & 2,314 & 2,297 & 2,774 & 2,973 & 2,973 \\
\hline Number of individuals & 618 & 670 & 744 & 592 & 587 & 722 & 802 & 802 \\
\hline R-squared & 0.020 & 0.019 & 0.026 & 0.025 & 0.025 & 0.021 & 0.026 & 0.024 \\
\hline
\end{tabular}

Note: Standard errors in parentheses; $* * \mathrm{p}<0.01,{ }^{*} \mathrm{p}<0.05$; Source: SHP 1999-2016. 
Table A9: Buffering effect for disability: psychological resources

\begin{tabular}{|c|c|c|c|c|c|}
\hline & Conscientiousness & Openness & Agreeableness & Extraversion & Neuroticism \\
\hline \multirow[t]{2}{*}{ One year before } & 0.418 & -0.278 & 0.811 & -0.462 & 0.005 \\
\hline & $(0.337)$ & $(0.406)$ & $(0.464)$ & $(0.344)$ & $(0.285)$ \\
\hline \multirow[t]{2}{*}{ Shortly after } & -0.438 & 0.302 & -0.364 & -0.289 & -0.465 \\
\hline & $(0.331)$ & $(0.397)$ & $(0.453)$ & $(0.338)$ & $(0.280)$ \\
\hline \multirow[t]{2}{*}{ One year after } & -0.498 & -0.169 & $-1.017^{*}$ & -0.350 & -0.061 \\
\hline & $(0.356)$ & $(0.438)$ & $(0.491)$ & $(0.362)$ & $(0.311)$ \\
\hline \multirow[t]{2}{*}{ Two years after } & 0.037 & 0.257 & $-1.135^{*}$ & -0.202 & -0.056 \\
\hline & $(0.369)$ & $(0.445)$ & $(0.514)$ & $(0.377)$ & $(0.328)$ \\
\hline \multirow[t]{2}{*}{ One year before $*$ buffer } & -0.846 & 0.222 & $-1.345^{*}$ & 0.687 & -0.288 \\
\hline & $(0.493)$ & $(0.609)$ & $(0.644)$ & $(0.697)$ & $(0.550)$ \\
\hline \multirow[t]{2}{*}{ Shortly after * buffer } & -0.074 & $-1.199^{*}$ & -0.173 & -0.397 & 0.002 \\
\hline & $(0.484)$ & $(0.596)$ & $(0.630)$ & $(0.682)$ & $(0.543)$ \\
\hline \multirow[t]{2}{*}{ One year after * buffer } & 0.121 & -0.398 & 0.852 & -0.148 & -0.693 \\
\hline & $(0.524)$ & $(0.662)$ & $(0.685)$ & $(0.735)$ & $(0.594)$ \\
\hline \multirow[t]{2}{*}{ Two year after * buffer } & -0.216 & -0.544 & $1.516^{*}$ & 0.252 & -0.019 \\
\hline & $(0.542)$ & $(0.674)$ & (0.719) & $(0.764)$ & $(0.628)$ \\
\hline \multirow[t]{2}{*}{ Constant } & $7.424^{* *}$ & $7.404^{* *}$ & $7.427 * *$ & $7.412^{* *}$ & $7.418^{* *}$ \\
\hline & $(0.073)$ & $(0.073)$ & $(0.073)$ & $(0.073)$ & $(0.073)$ \\
\hline Observations & 1,730 & 1,715 & 1,733 & 1,727 & 1,728 \\
\hline Number of individuals & 422 & 418 & 423 & 422 & 422 \\
\hline R-squared & 0.030 & 0.032 & 0.042 & 0.029 & 0.028 \\
\hline
\end{tabular}

Note: Standard errors in parentheses; ** $\mathrm{p}<0.01,{ }^{*} \mathrm{p}<0.05$; Source: SHP 1999-2016. 
